\title{
قراءة لكتاب مسؤولية التأويل \\ تأليف: مصطفى ناصف
}

*** خالد عبد الرؤوف الجبر

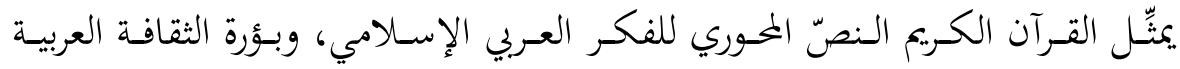

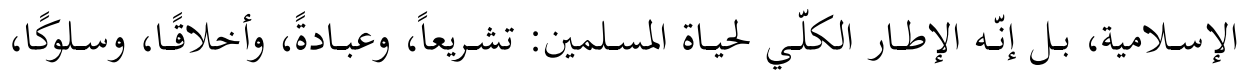

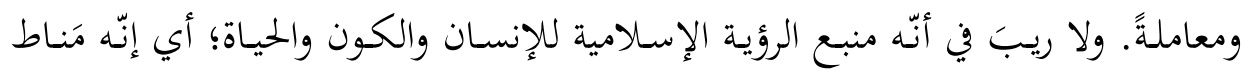

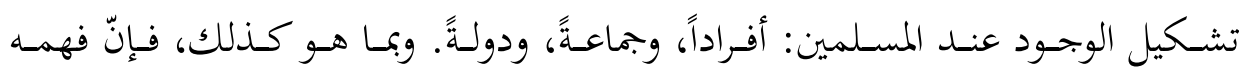

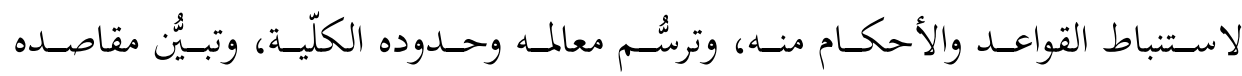

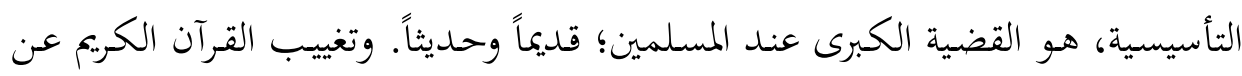

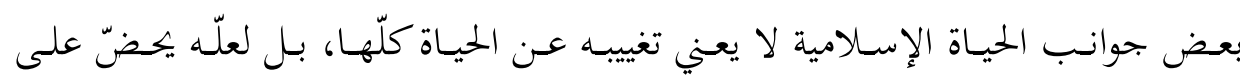

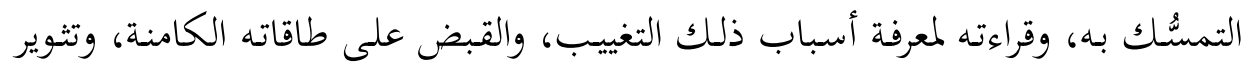
إمكاناته في تأسيس بحتمع إنساني إسلامي.

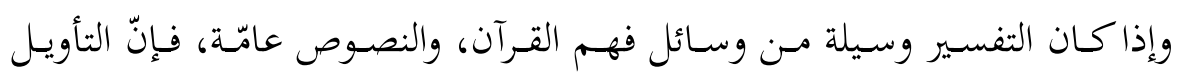

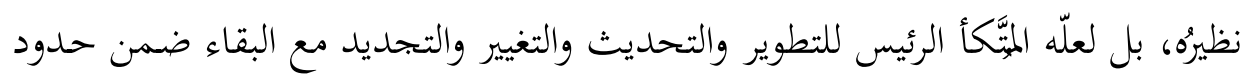

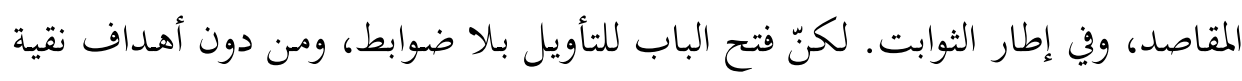

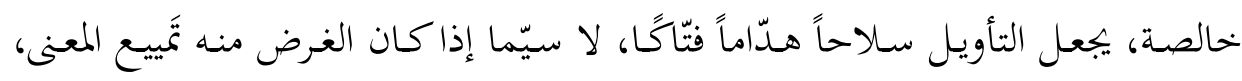

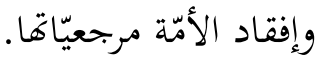

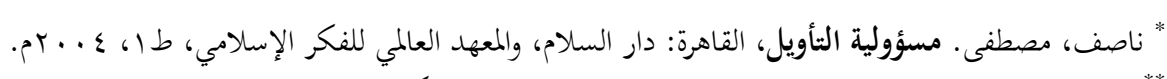

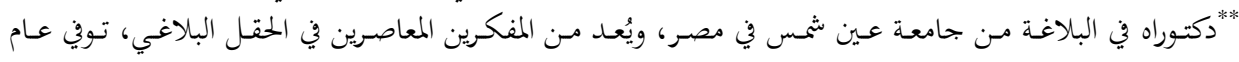

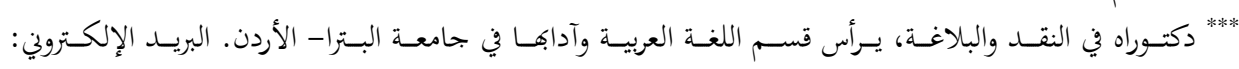
jabr_khalid@yahoo.com

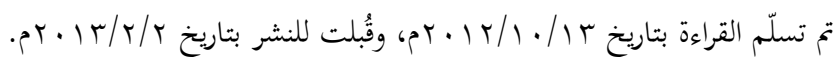


ومن هنا تنبع أهمية الكتاب، خاصّة إذا علمنا أنّ مؤَلِّهـ ناقد متميِّز اجتمع له النظر

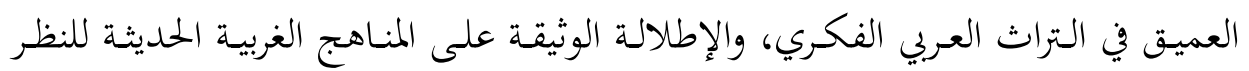

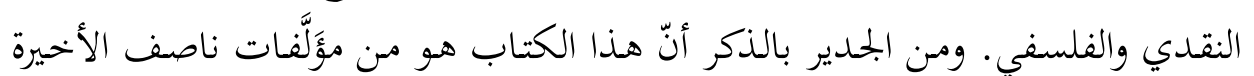
التي تمثّل زُبدة فكره، وخحلاصة رحلته الطويلة مع البحث العلمي. جاء الكتاب في مقدّمة موجزة، وعشرة فصول هي: الثقافة العربية والتأويل، ومبادئ

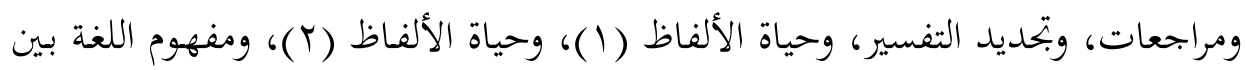

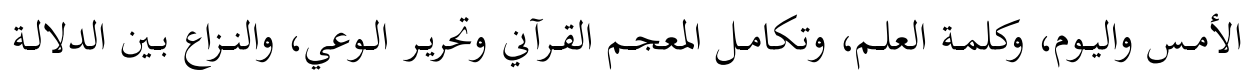

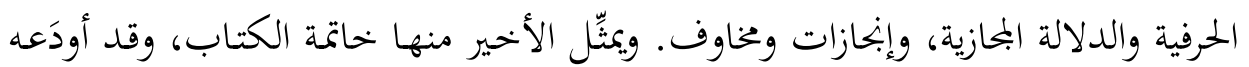

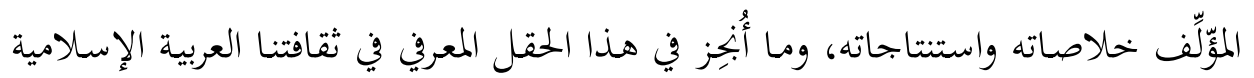
على مدار قرون. ولم يُغِفل مـا يكتنف موضوع التأويل من مخاوف؛ لأنّه بفتح الأبواب

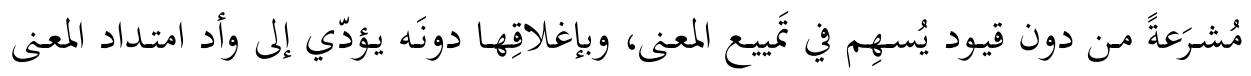

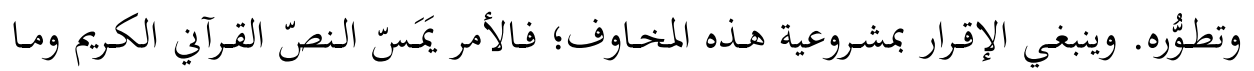

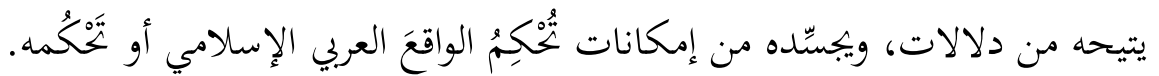
والقِرانُ الذذي عقدَه المؤَلِّف، في المقدّمهة، بين التأويل الذَي هو سمـة العصر، وعِفّة

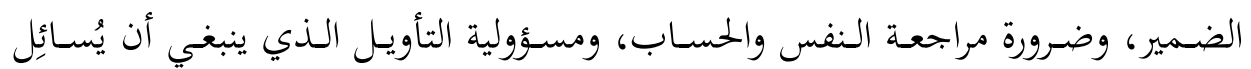

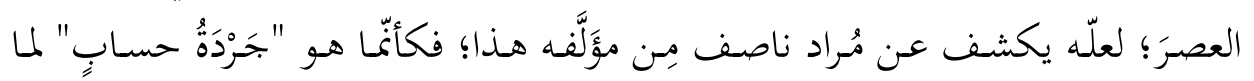

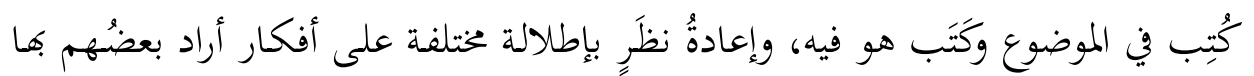

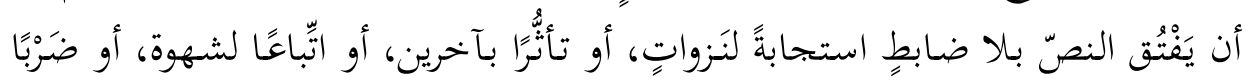

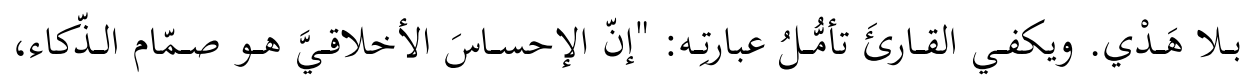

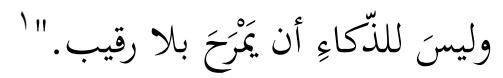

تُمثّل الفصول الثلاثة الأولى من الكتاب جوهره الفكري، ورؤية مؤَلِّفه الخاصِّة. وسائرُ

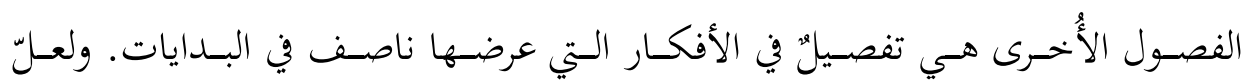

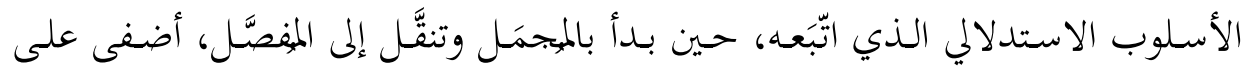


الكتاب صبغةً خاصَةً مثَّلت بيانَه الخاصّ، وأسندَتْ رغبتَه في إبلاغ رؤيته للقارئ بمنطقية وتسلسُل.

ناقش ناصف في الفصل الأول منزلةً التأويل في الثقافة العربية، وعالقَ بصورة فريدة

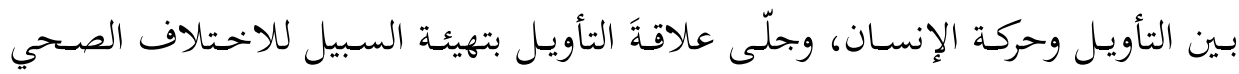

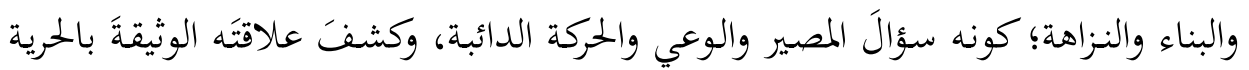

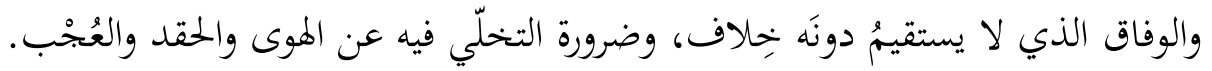
لقـد نظر ناصف إلى التأويل بوصفه صـنوَ الاختلاف لا الخـلاف، وبتسيدًا للرقي

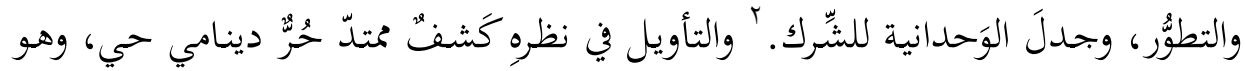

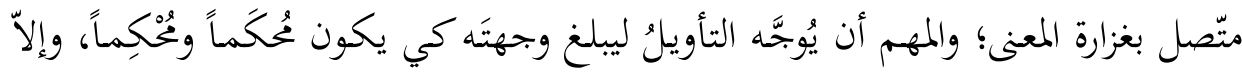

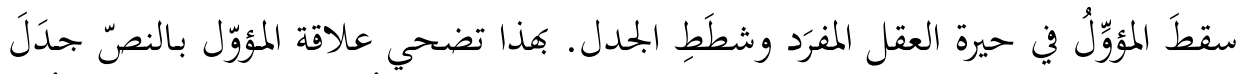

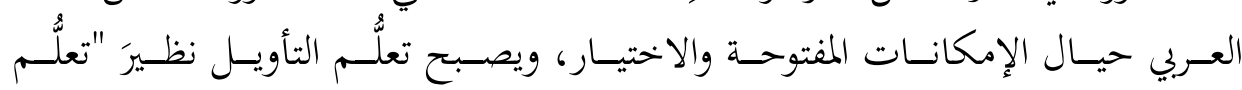

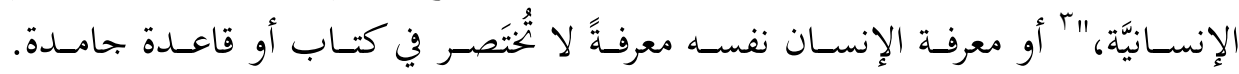

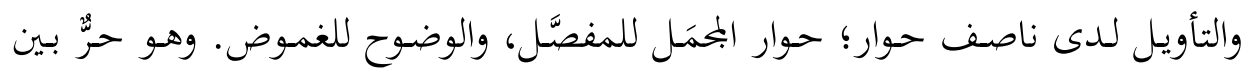
جماعةٍ أحرار بتسيدًا لدرس الاختيار والمساءلة وحقوق الإنسان.

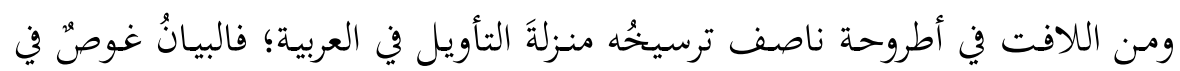

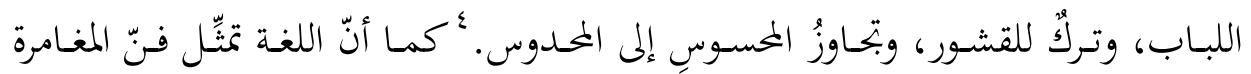

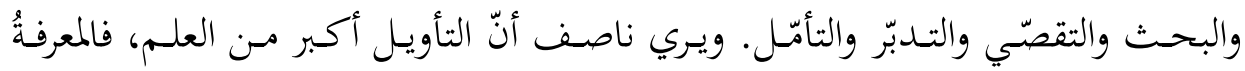

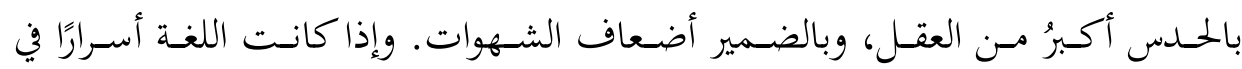

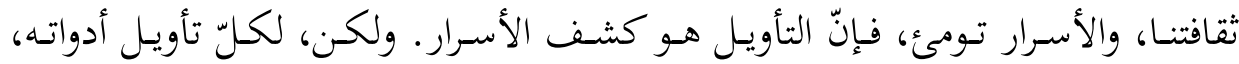

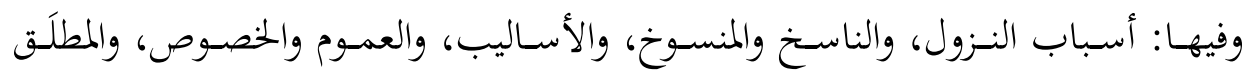

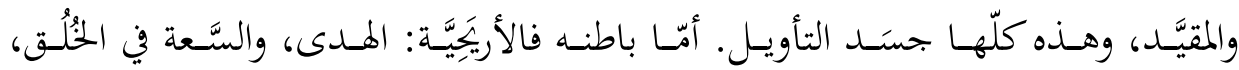
والاستعداد للعطاء، والشوقُ. وأمّا مطلَبُه فالرُّوح. 
ويقرّر ناصف قاعدة كبرى مفادها أنّ النصّ أكبر من التأويل، وهو منبعه ومآله، ولا

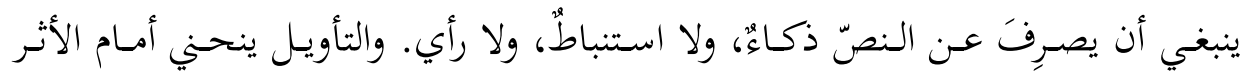
والرجوع والجماعة والقدوة والنقاء. والغاية الكبرى في تراثنا إعظامُ النصّ نفسه، وبعبارته:

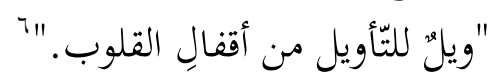

وإذا كانت مفاتيح التأويل والتفسير لغوية، بمـا أبقى التحليل الفيلولوجي عُمدة كلّ جهد، فإنّ اللغة وجوه قد تلتقي لتكون وجهاً حيناً، وقد تفترق ليكون الاختلاف ولـ ومَنْ

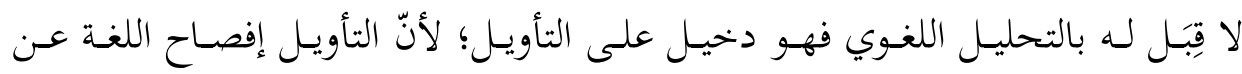
مكنوناتها.

ويمتـدّ ناصف بالنقاش ليتعرض لمخـاطر التأويل. فبإذاكـان تعريفه الأصسيل "صرفَ

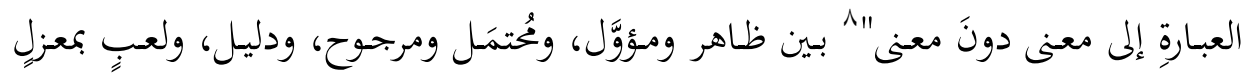

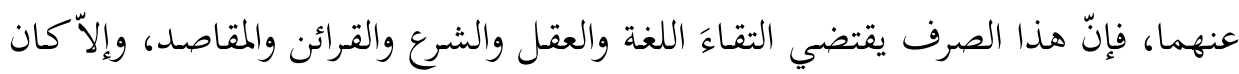

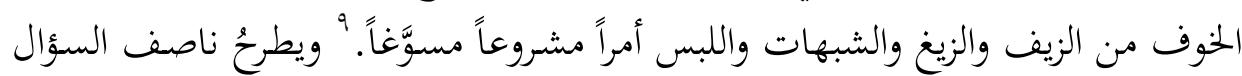

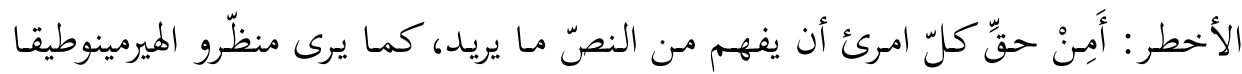

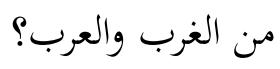

يرى ناصف أنّ اللغة والحقيقة والشرع أقانيمُ ثلاثة تختلف وتأتلف، ولا يمكن فحص

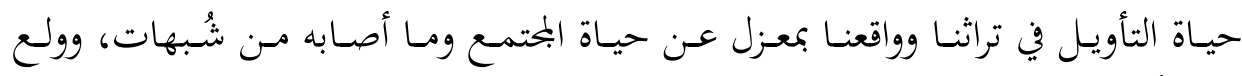

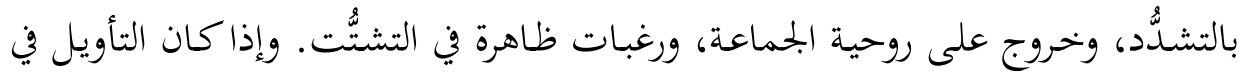

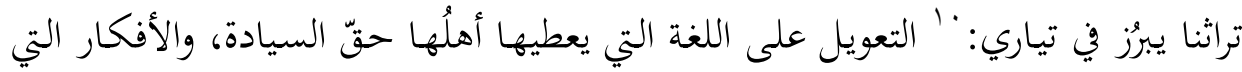

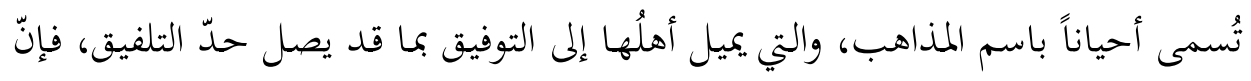
الخوف من الزيغ يظلّ مشروعاً أيضاً.

ويفِّق ناصف بين تأويل يخدم النصَّ، وآخرَ يُرهِقه ويُتنقِله ويُحمِّله ما لا يحتمل. ويرى

$$
\begin{aligned}
& \text { " المرجع السابق، صץ ا . } \\
& \text { " المرجع السابق، صرجع الساب، صبا. }
\end{aligned}
$$

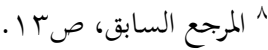

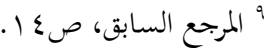

$$
\begin{aligned}
& \text { ' ' المرجع السابق، صع الساب، صع ا. }
\end{aligned}
$$




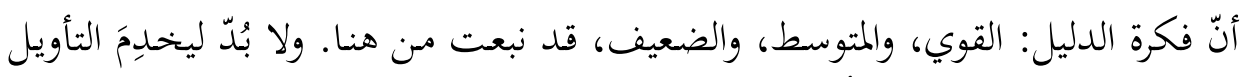

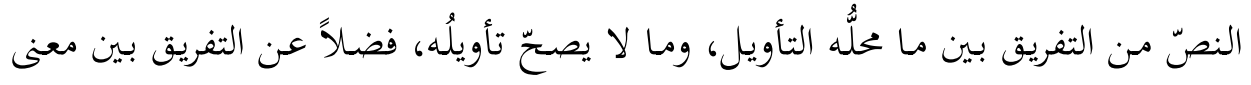

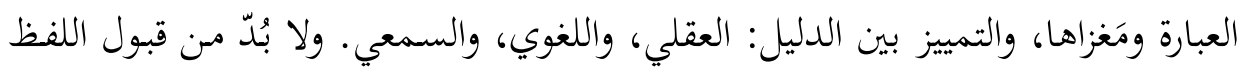

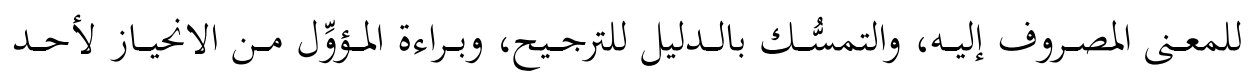

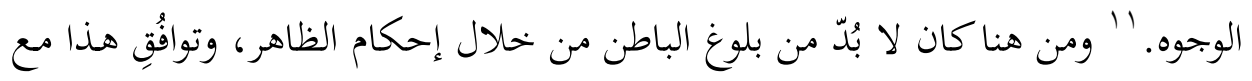

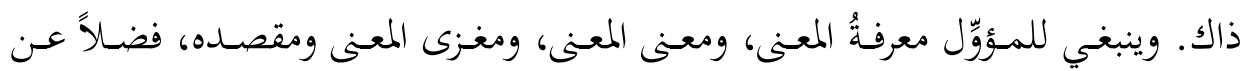

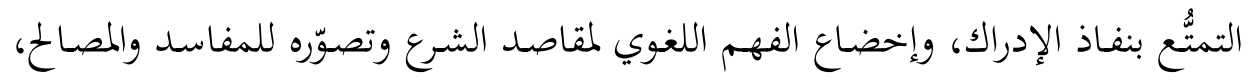
والتنبُه على اختلاف مدلول الفهم اللغوي بتنوُُع البيئات.

إنّ الاختلاف في التأويل المنزّه عن الأهواء -كما يرى ناصف-هو اختلاف على: طاقات اللغة، ومواجهة الحياة المتغيّرة، والخوف على اللغة نفسها، وعلى الأمّة ومصيرها.

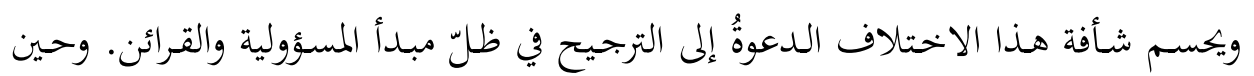

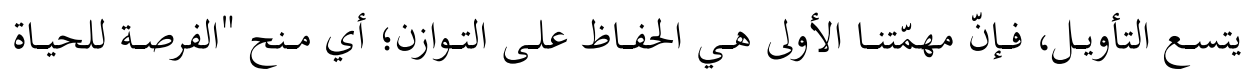

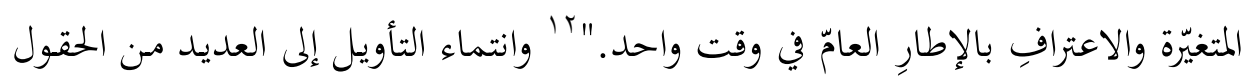

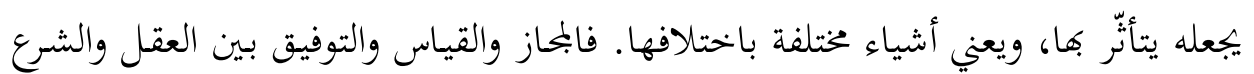

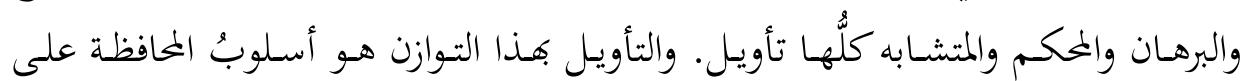

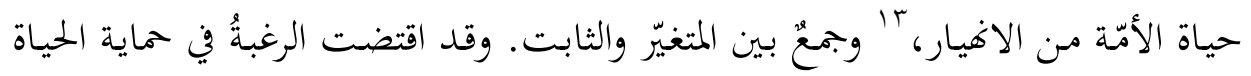

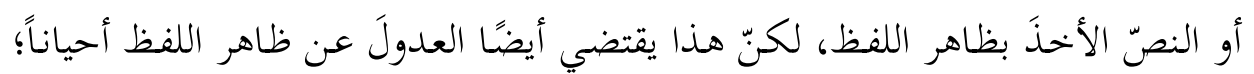

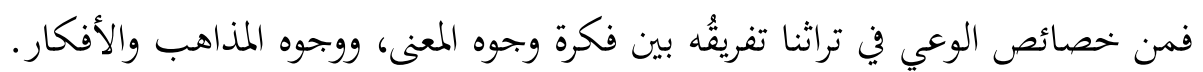
ويستدرج ناصف القارئَ بَتَؤدةٍ نحو غايته الكبرى؛ فهو يعرض لغاية الأصوليين من

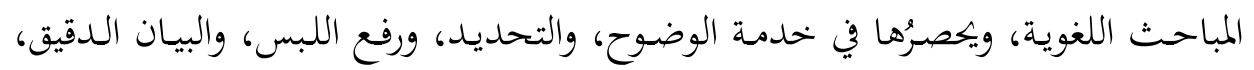

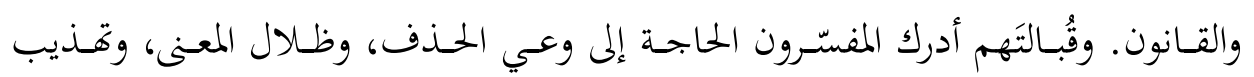

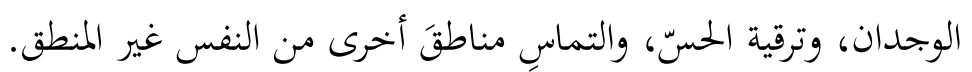

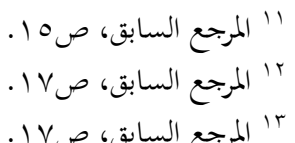
r" المرجع السابق، صلا صلا وهو يعيد الفكرة إلى الإمام السيوطي في كتابه "الإتقان في علوم القرآن". 
وبما أنّ غاية الأصوليين من اللغة هي التشريع فقد التّعوا منهجاً عقليّاً منطقيّاً، خلافاً

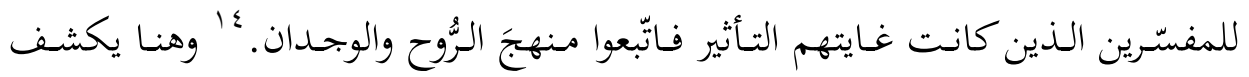

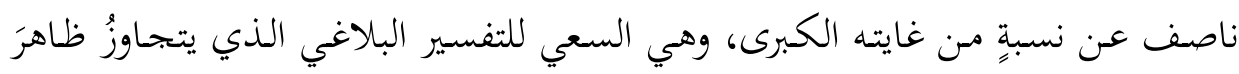

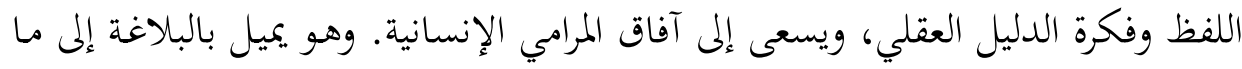

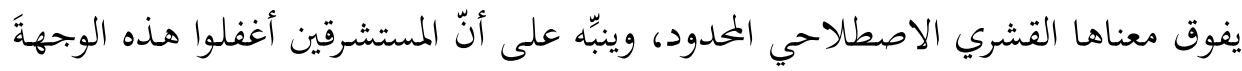
عمدًا في دراساقم. 10

ويرى ناصف أنّ علماءَنا أدركوا الفرق العميق بين البيان اليوناني والمنطق الصوري من آنس

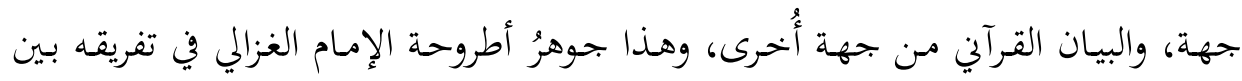

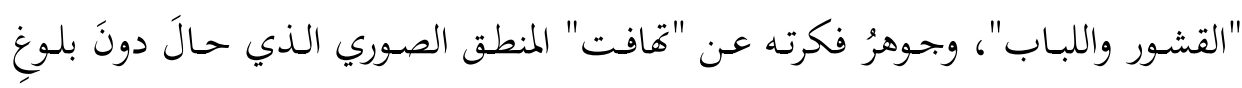

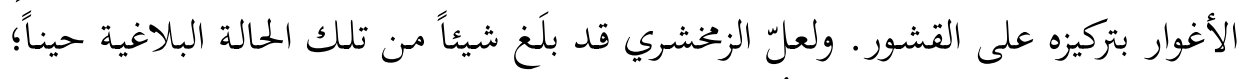

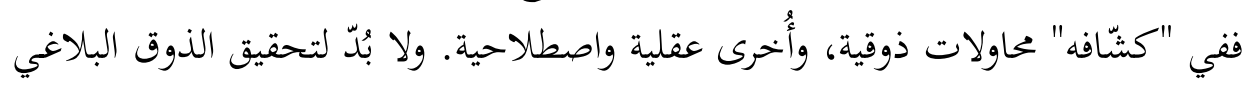
من القراءة المستمرّة الحية، والاشتغال القلبي بالمعنى. 17

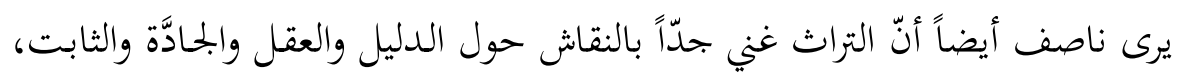

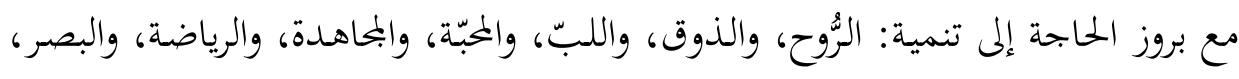

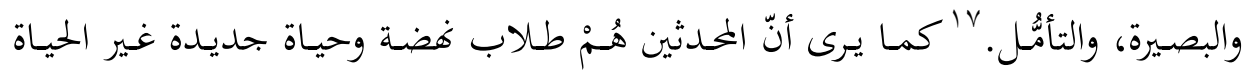

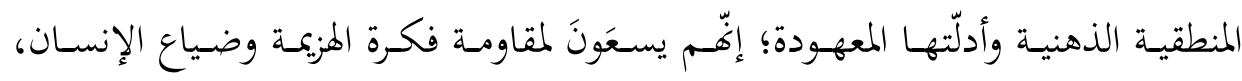

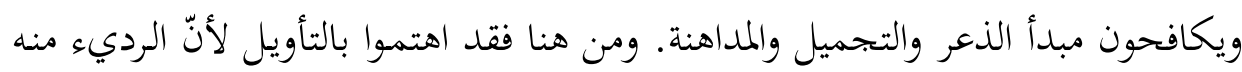

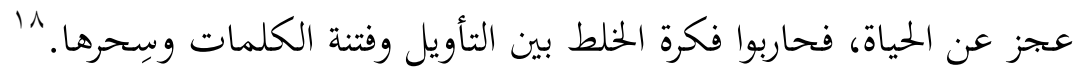

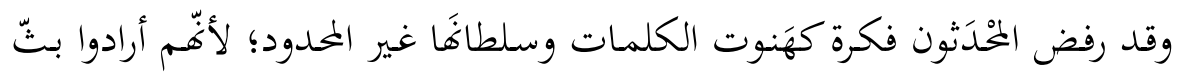

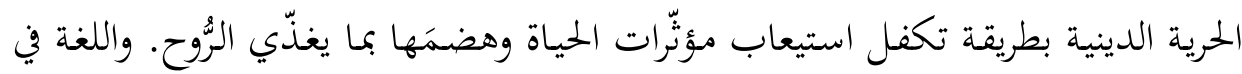

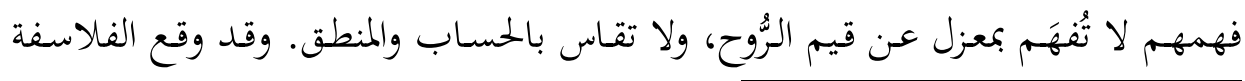

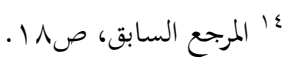

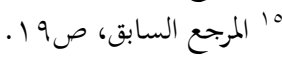

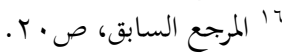

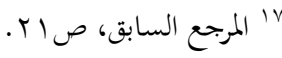

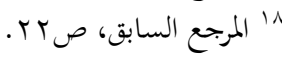




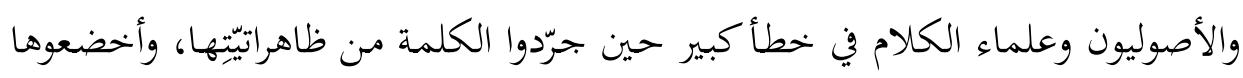

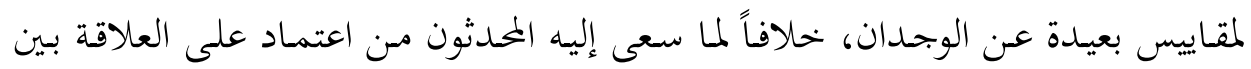

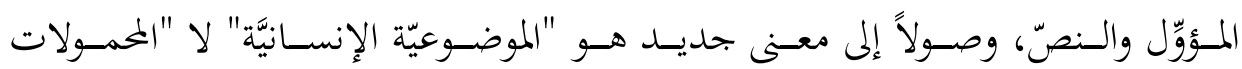

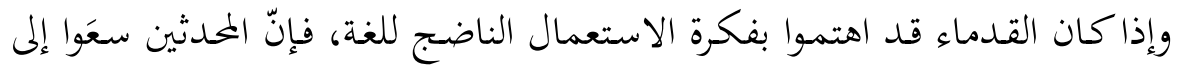

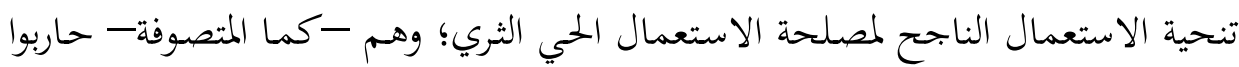

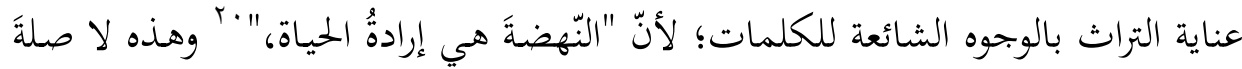

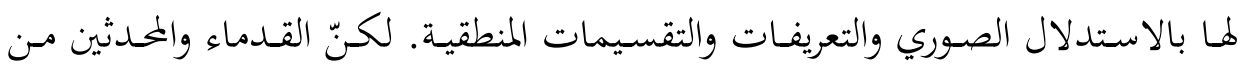

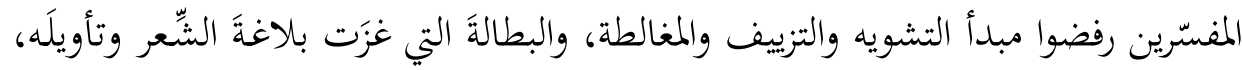

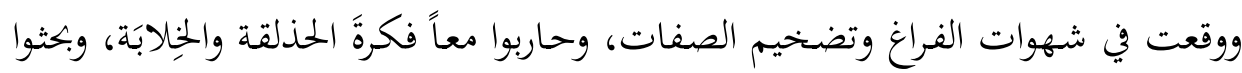

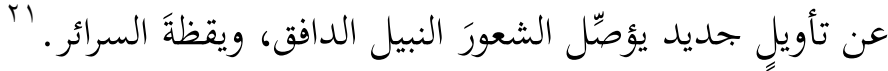

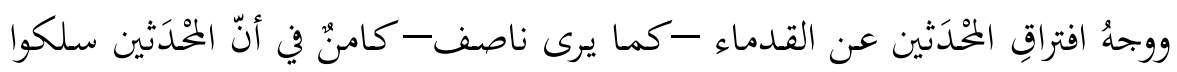

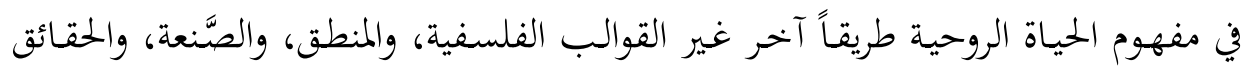

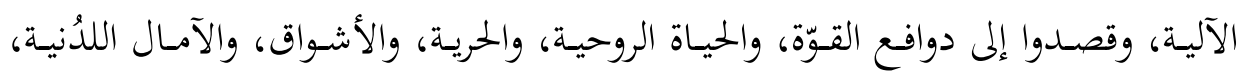

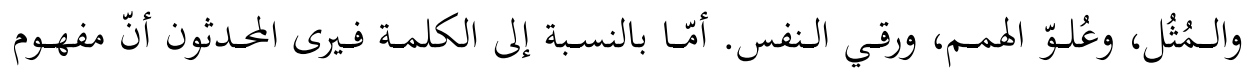

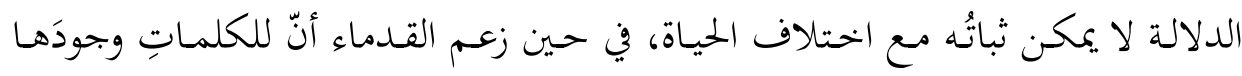

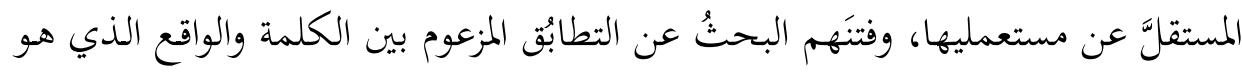

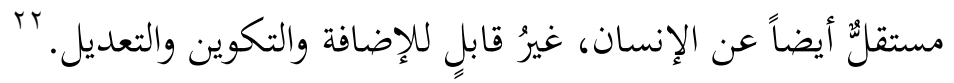

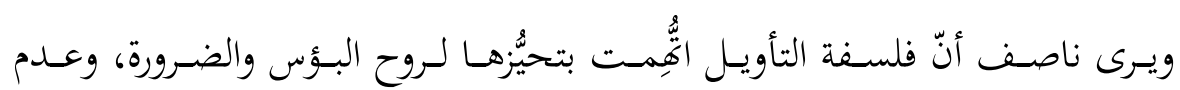

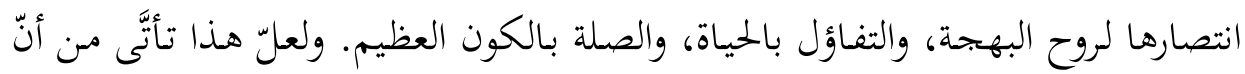

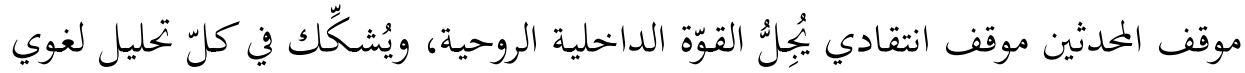
قديم أو حديث لا يُعنى بهذه القوّة.

$$
\begin{aligned}
& \text { 19 المرجع السابق، صبr ب. }
\end{aligned}
$$

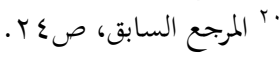

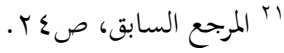

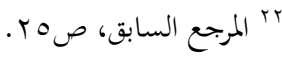


ويعتقـد ناصف بدقة ملاحظة المحلثين في تنبُّهُهم على أنّ لكلّ معنى أمسارةً مادية،

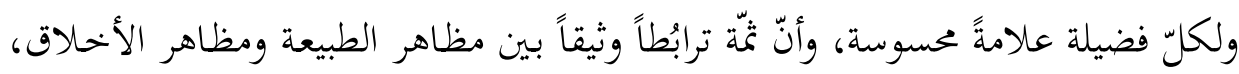

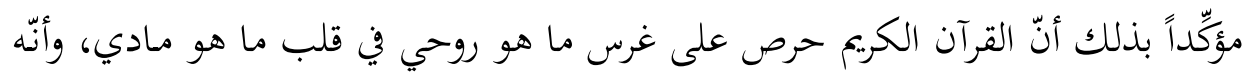

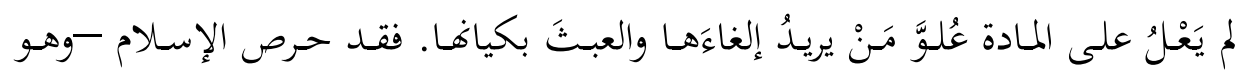

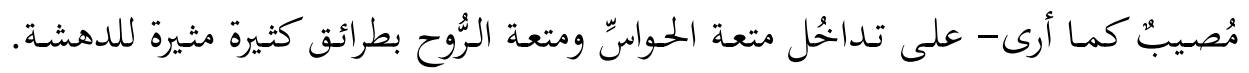

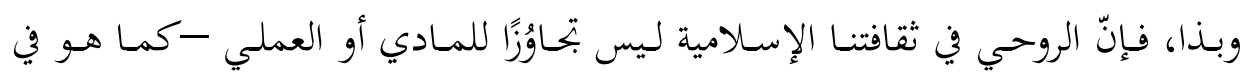

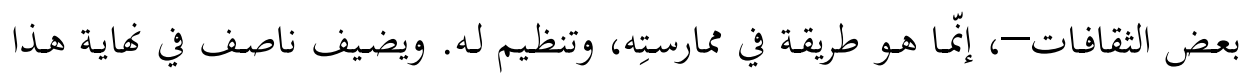

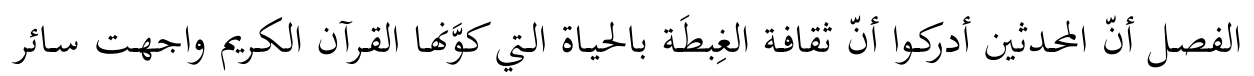

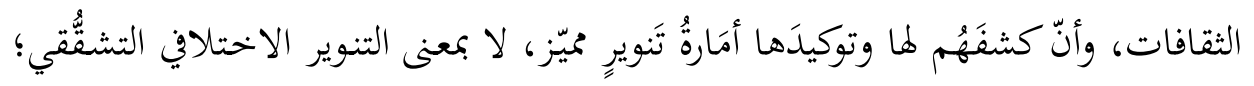

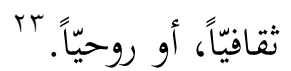

أمّا الفصل الثـاني فنـاقش فيـه ناصـف فصـل الظواهر اللغويـة أو البيانيـة عـن الخـبرة

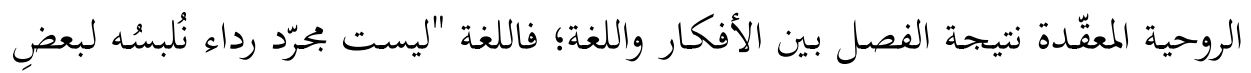

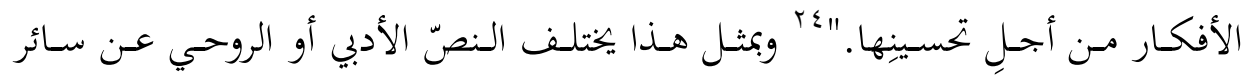

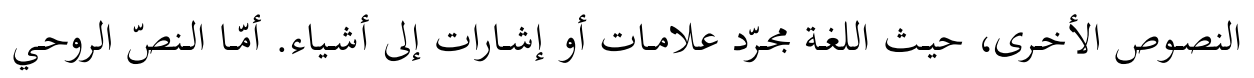

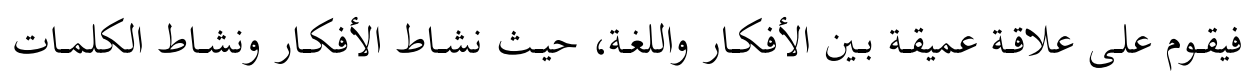
شيء واحد.

وين النصّ العلمي العقلي يختلف الأمر عن النصّ البليغ؛ إذ نفهم المعاني المقصودة

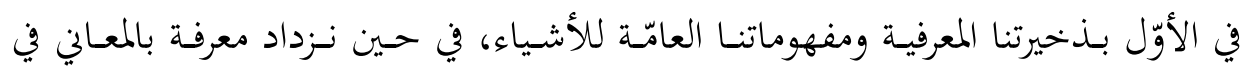

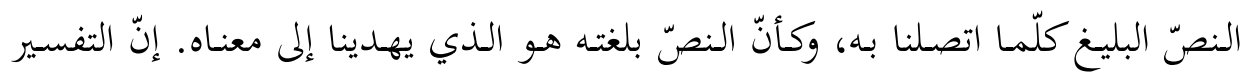

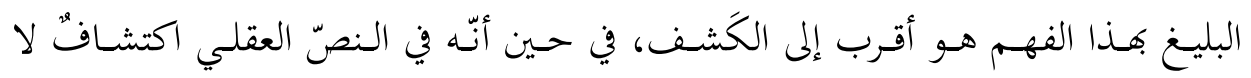
غير.

وإذاكانـت مهمّة المفسِّر هي الربط بـين الأفكار واللغـة، وخهـلا المحال اللغـوي مـن

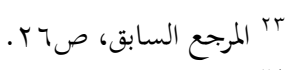

$$
\begin{aligned}
& \text { ء المرجع السابق، ص ابr. }
\end{aligned}
$$

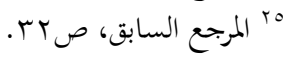




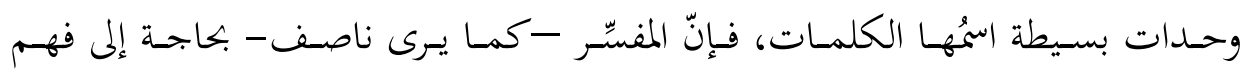

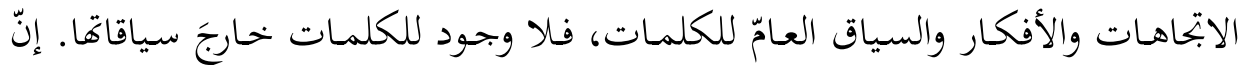

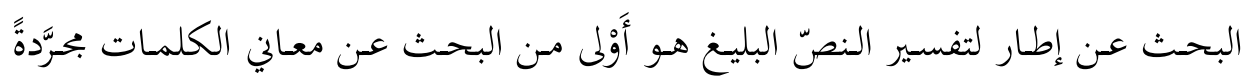

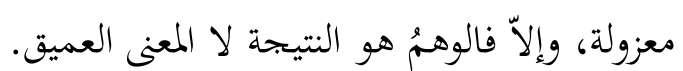

كان المفسّرون ينطلقون مـ الكلمات بوصف النصّ مكوَّناً مـن وححدات كلامية،

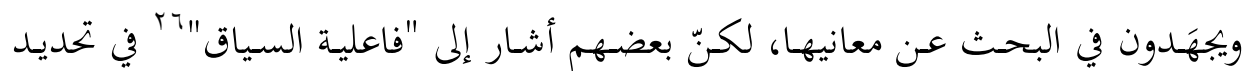

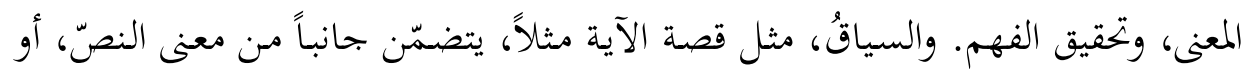
يُضيء معناه، لكنّهما ليسا الأمرَ نفسَه. وإذا كان المفسِّرون القدماء قد قعَّدوا رؤيةً "العبرة

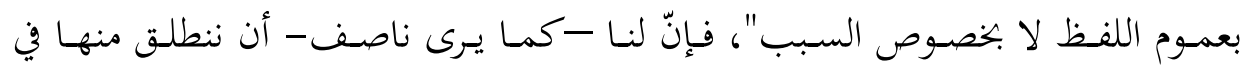

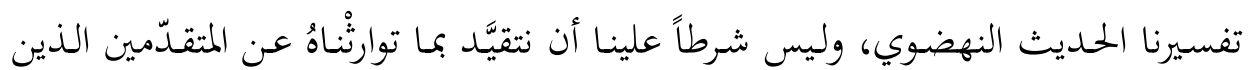

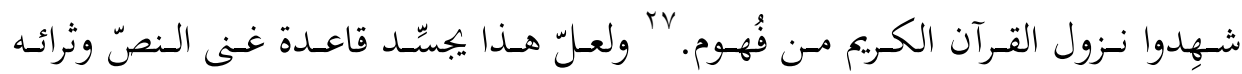

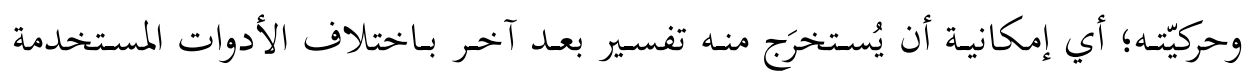
وطبيعتها، وباختلاف الواقع والحال.

وليس ينبغي لأحسد النظرُ في ظروف نزول الآيات أو السّور بوصفها محسِّدةً مثبِّنةً

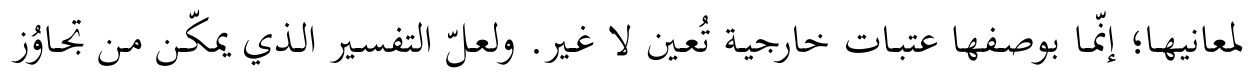

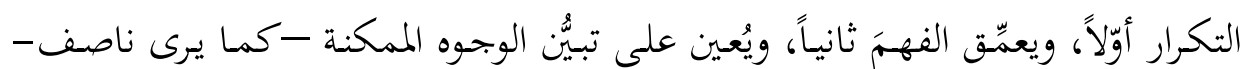

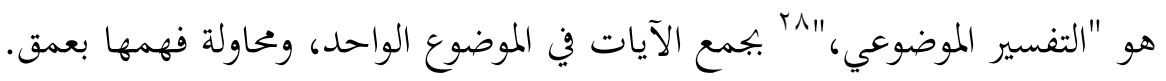
ولا بُدّ في هذا الإطار من التغريق بين فهم الخاصّة، وفهم العامّة، ولهذاكان القدماء

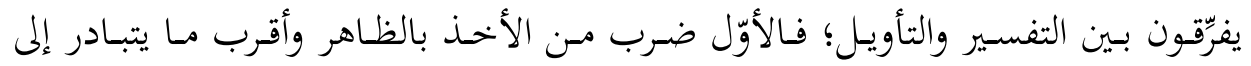

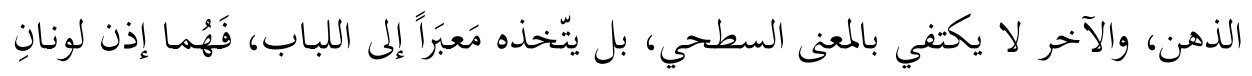
من إدراك النصّ.

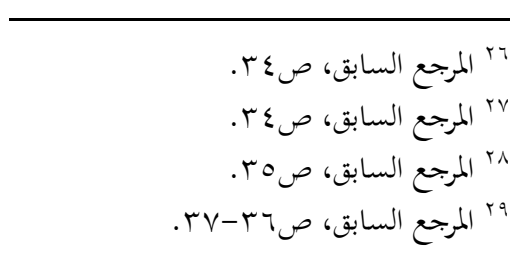


ويفرِّق ناصف بـين التأويل قـديماً والتفسير البليغ حـديثًا؛ فالتأويل -أحيانًا- أُطلِق

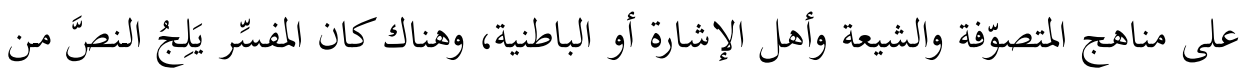

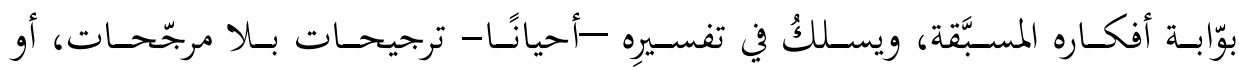

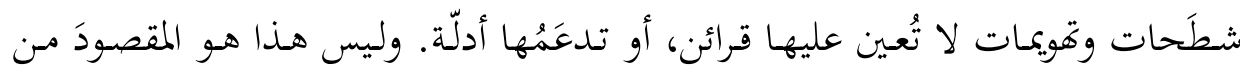

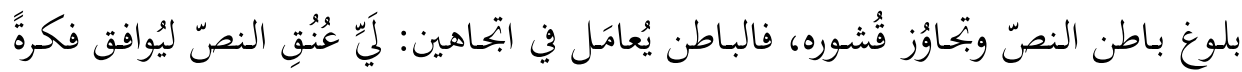

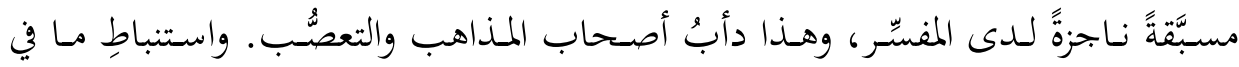

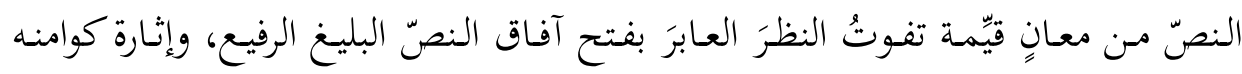

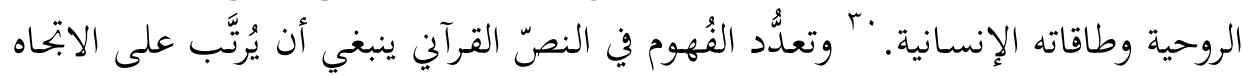

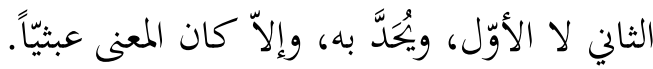

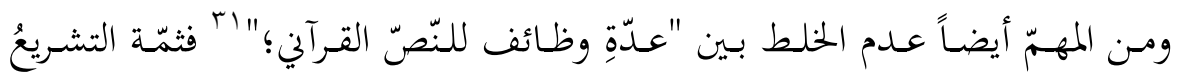

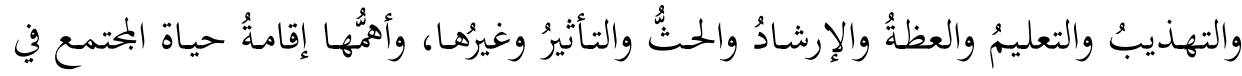

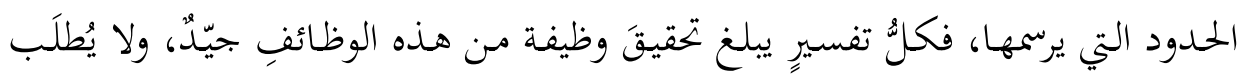

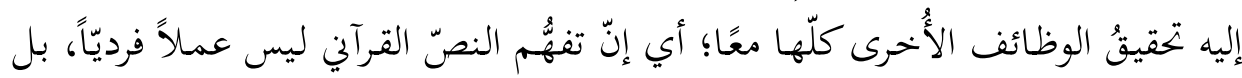

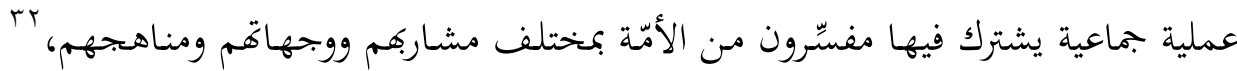

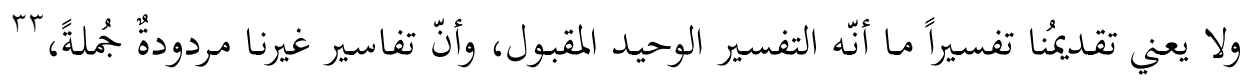

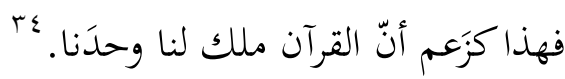

ويجب أيضاً أن يُؤخذ بحذر شديد تصنيفُ المحدثين للتفاسير القديمة: تفسيراً علميّاً،

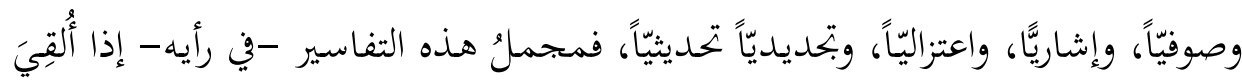

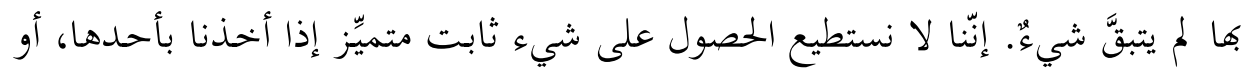

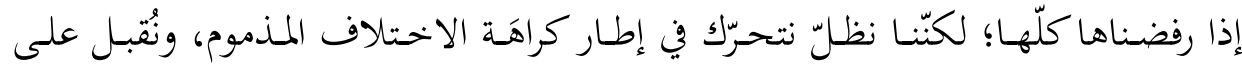

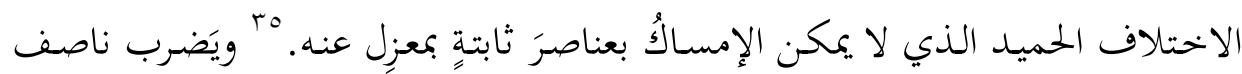

$$
\begin{aligned}
& \text { •r المرجع السابق، صVr. }
\end{aligned}
$$

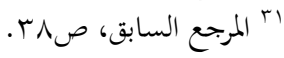

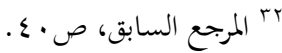

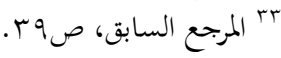

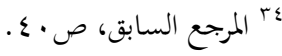

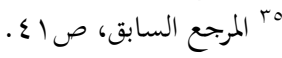




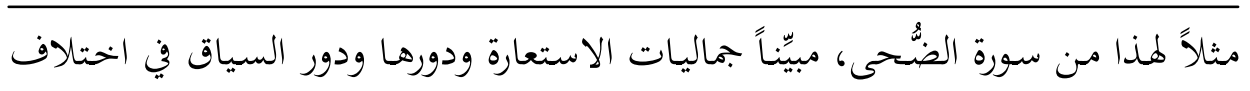

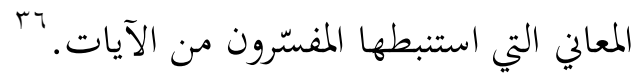

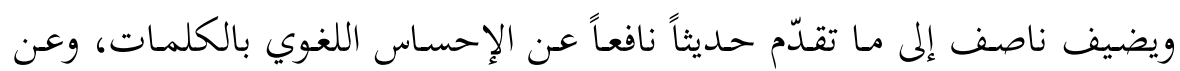

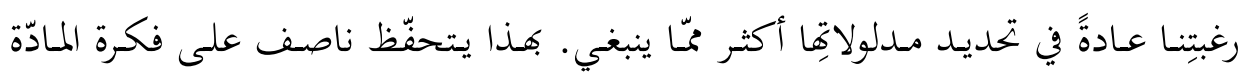

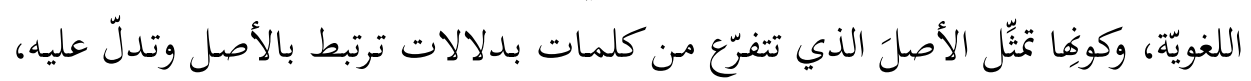

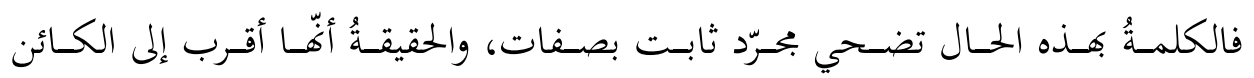

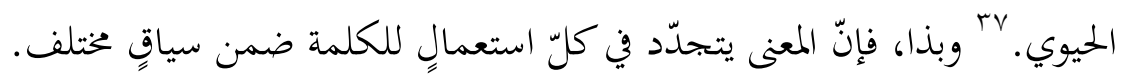

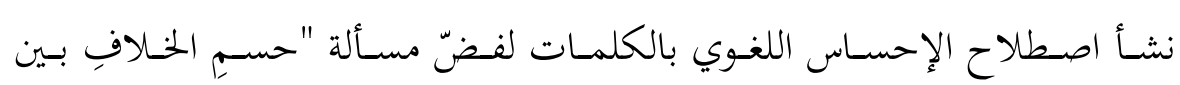

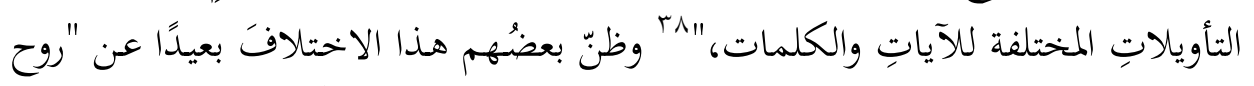

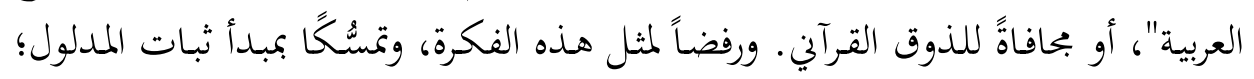

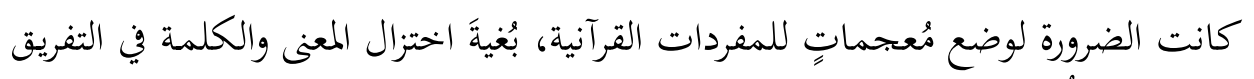

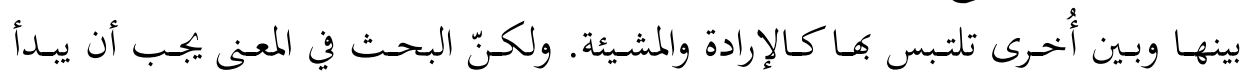

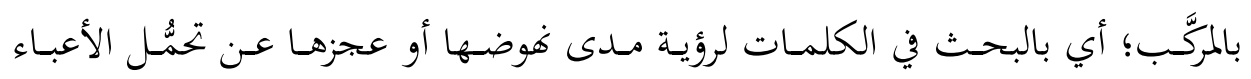
الفكرية المنوطة بالسياق.

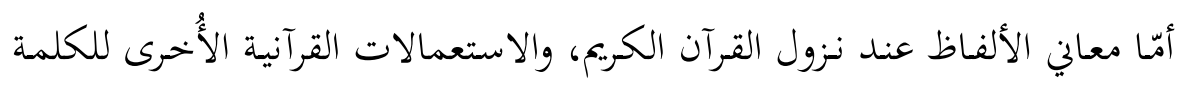

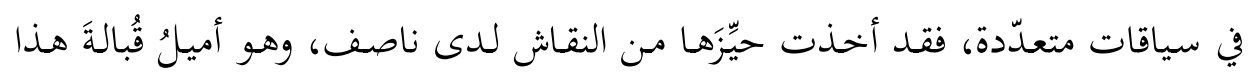

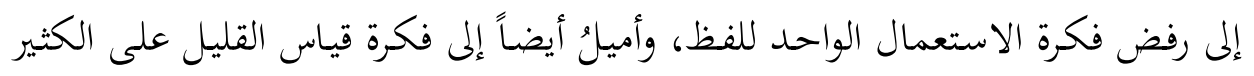

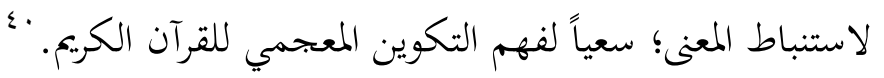

ولعلّ أخطر ما يناقشه ناصف في كتابه، هو فكرة "الثفسير الأدبي" للقرآن؛ وهو

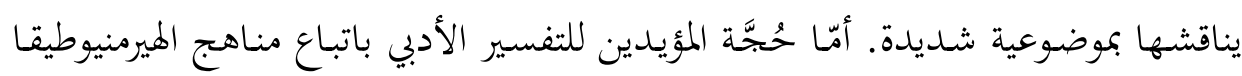

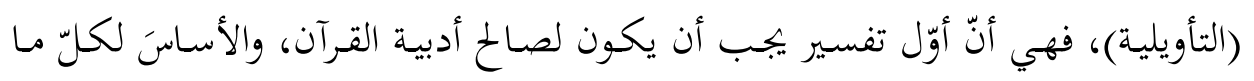

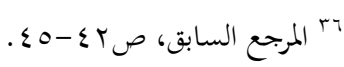

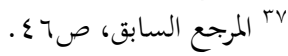

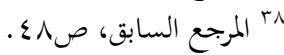

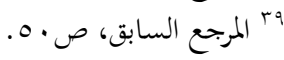

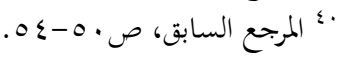




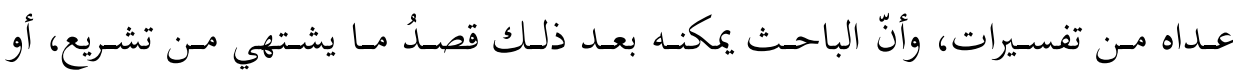

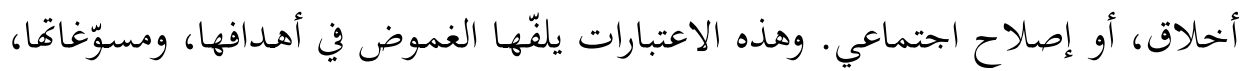

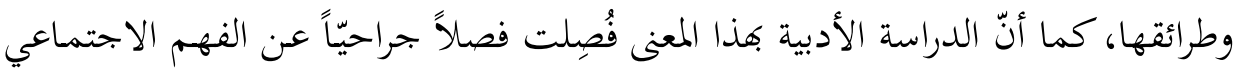

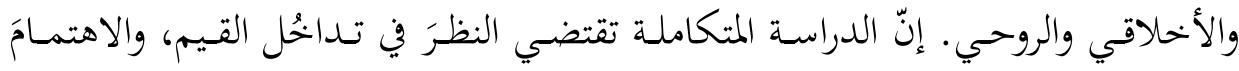

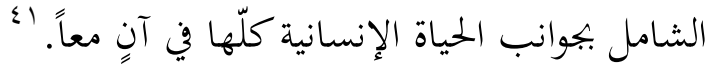

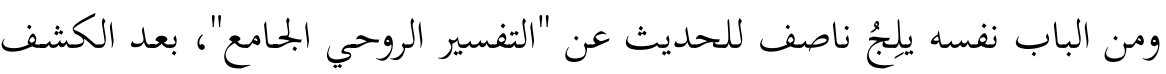

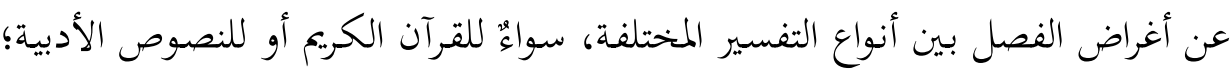

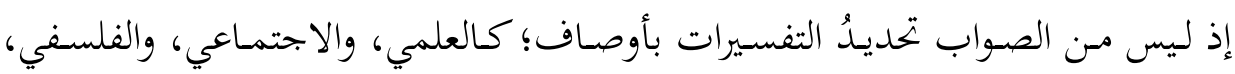

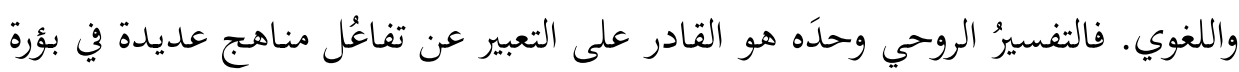

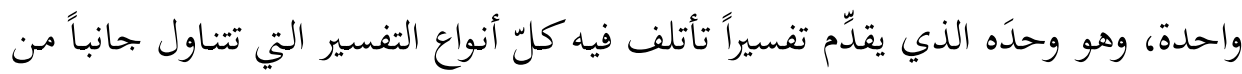

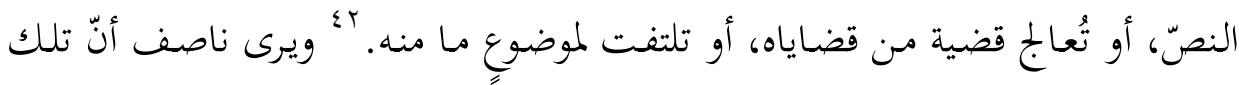

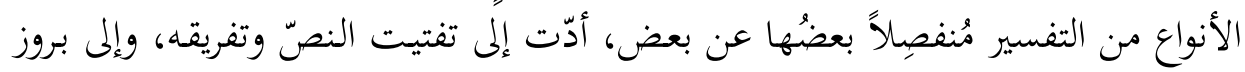

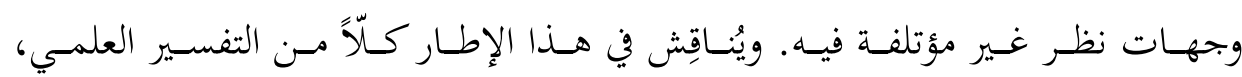

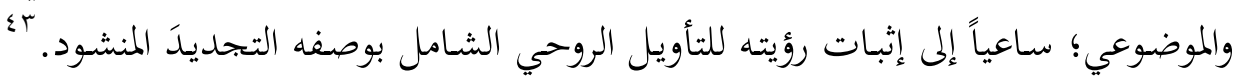

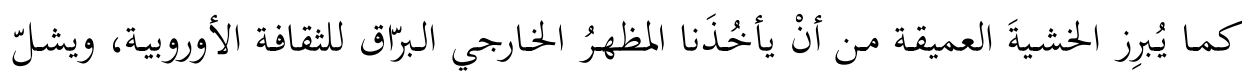

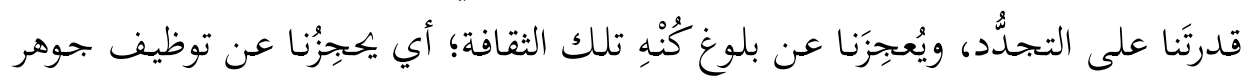

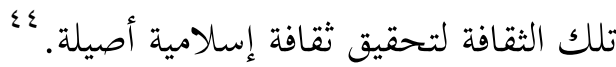

إنّ التجديد -مـن وجهة نظر ناصف- يتجسيّد في: العودة إلى بعض معالم التفكير

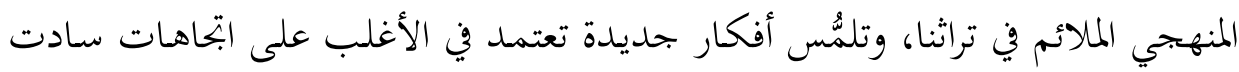

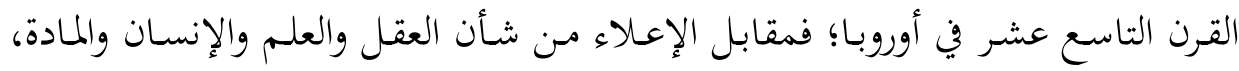

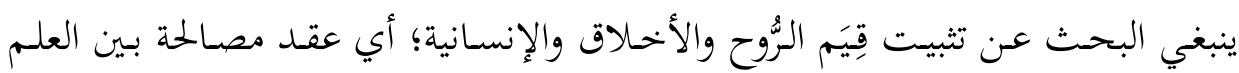

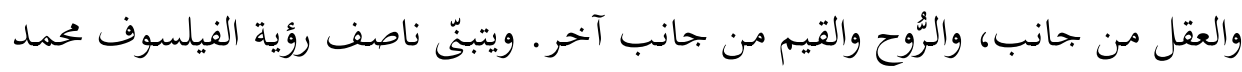

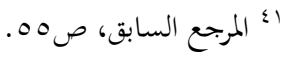

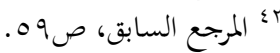

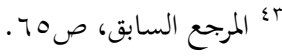

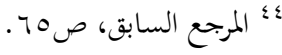


إقبال؛ التي مفادها احتياج الإنسانية إلى: تأويل الكون تأويلاً روحيّا، وتحرير رُوح الفرد،

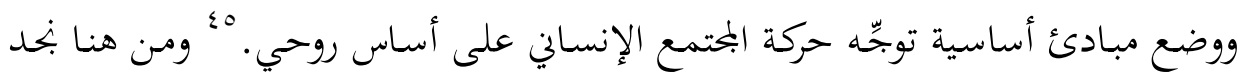

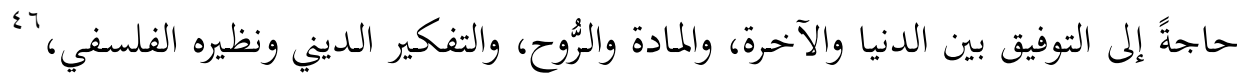

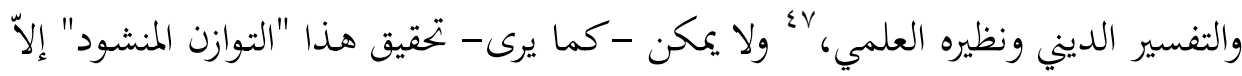

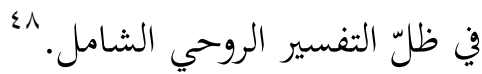
ويقدِّم ناصف في الفصل الثالث رؤيتَه للحساسية الروحية للكلمة في القرآن الكريم، وضرورة التمييز بين خطابنا نحنُ في التفسير، وخطاب الربِّ في القرآن الكريم، وخطاب فئه

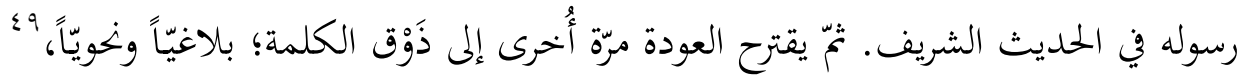

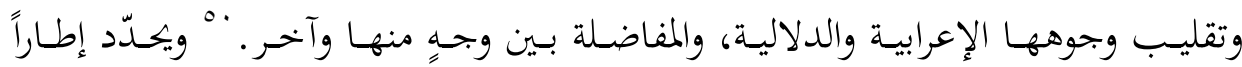

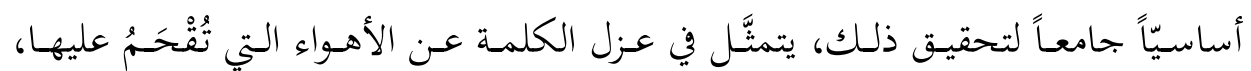

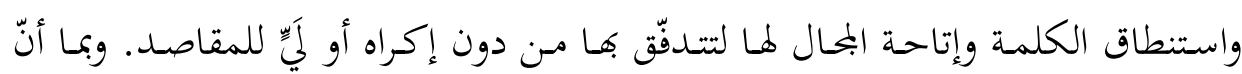

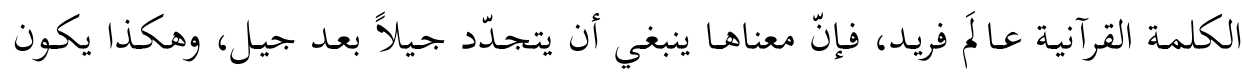

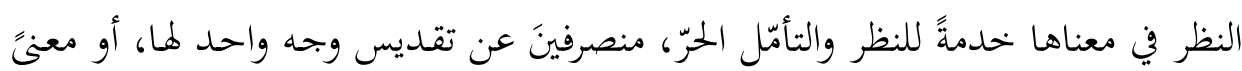

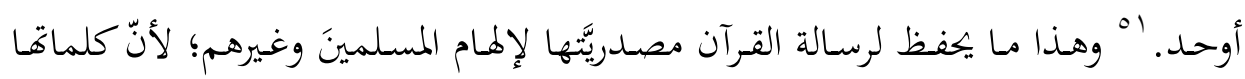

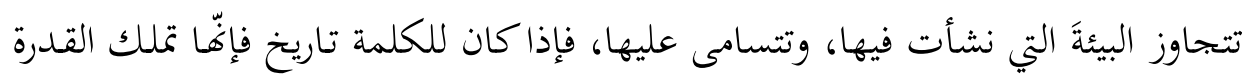

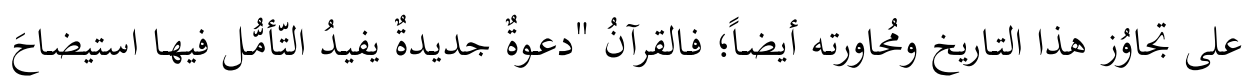

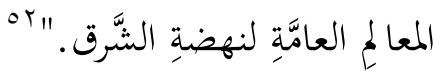

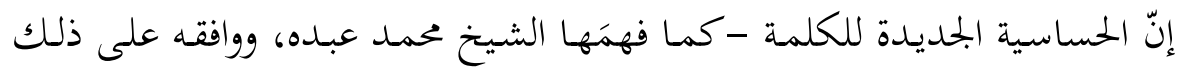
ناصف- هي نفسُها حساسية الحاجـة إلى النمو والتطوّر، والتطلّع إليه، ومعرفة أسبابه

$$
\begin{aligned}
& \text { ه؛ المرجع السابق، صلآ. }
\end{aligned}
$$

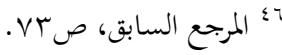

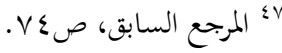

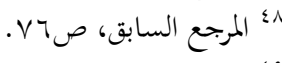

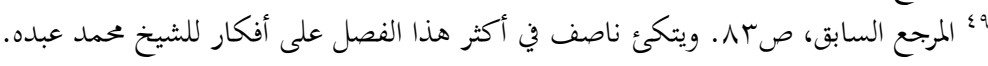

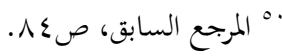

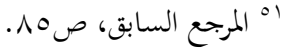

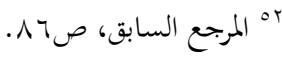


وعوائقه. ولا بُدّ من أن تكون الثقافة اللغوية منطلقَنا في حالٍ كهذه؛ بفهم المنابع الحقيقية

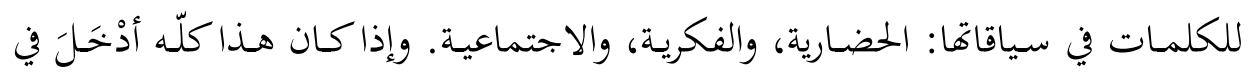

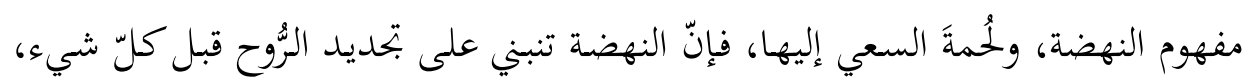

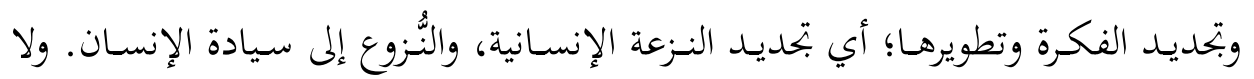
يكون ذلك من دون إدراك أنّ الحساسية اللغوية الصحيحة هي صحّة الالتحام، وإدراك عمق الروابط بين المادي العملي والروحي، والتمييز بين الخرافة والحقيقة. وقد مرّت الحساسية اللغوية الجحديدة في طورين اثنين: "أحدهما: التطوّر الاجتماعيّ

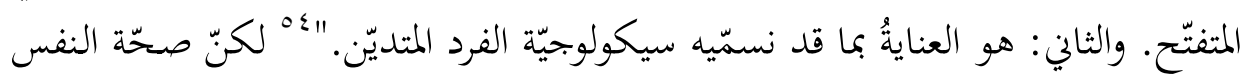

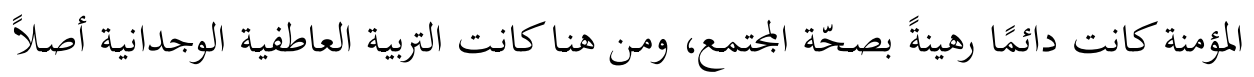

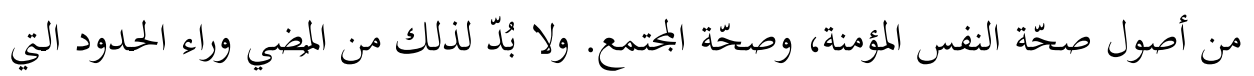

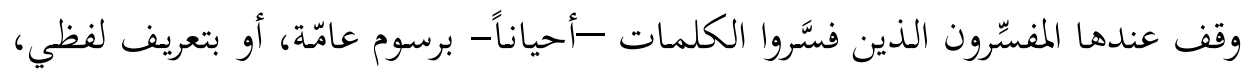

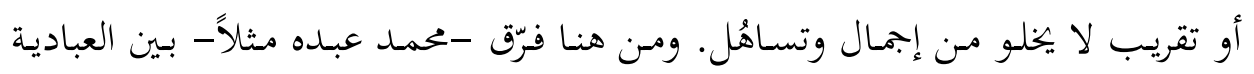

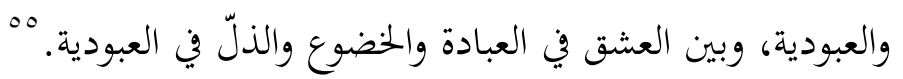

ويمضي ناصف في هذا الفصل متتبِعَاً آثنار الشيخ محمد عبده في التفسير، وبعض

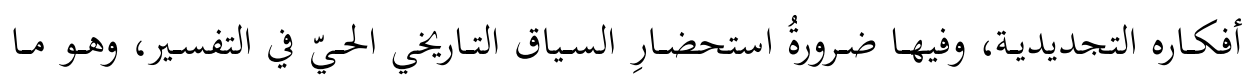

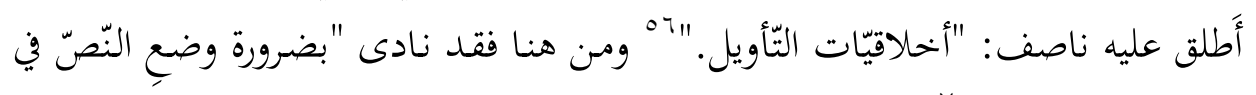

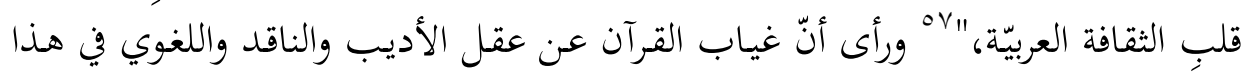

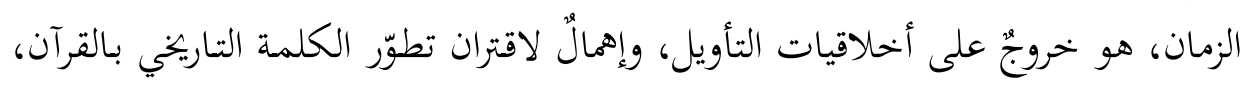

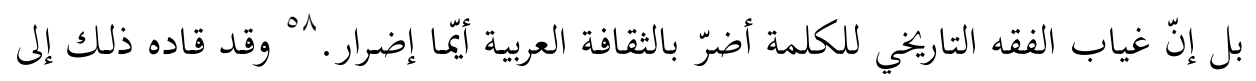

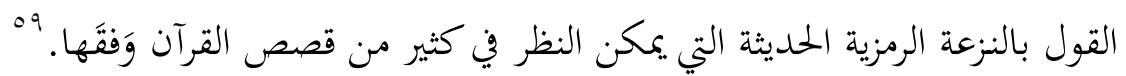

$$
\begin{aligned}
& \text { ro المرجع السابق، صلمV. }
\end{aligned}
$$

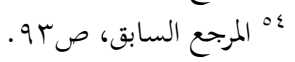

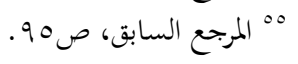

$$
\begin{aligned}
& \text { 7ه المرجع السابق، صو المرجع الساب، صو.9. }
\end{aligned}
$$

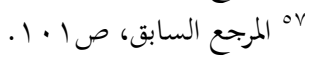

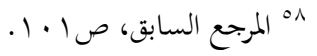

$$
\begin{aligned}
& \text { 9ه المرجع السابق، صرح السابق، ص . . 1. }
\end{aligned}
$$


هكذا تمتلك الكلمة القرآنية حركيََّها في الواقع، وفي الثقافة، وفي التاريخ، ولعلّ ذلك

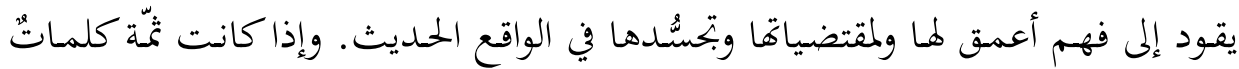

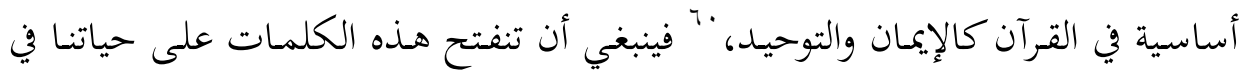

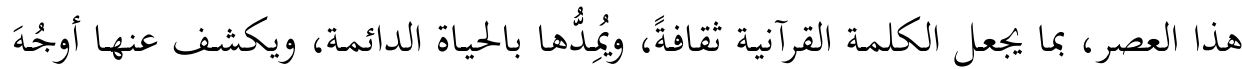

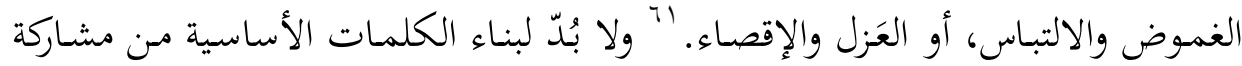

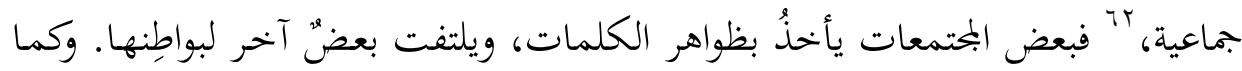

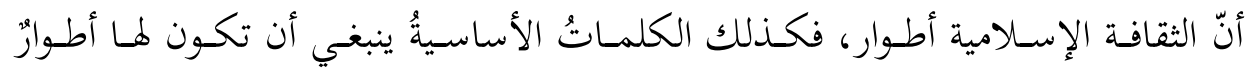

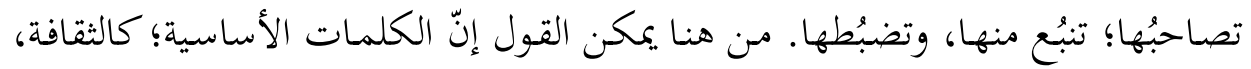

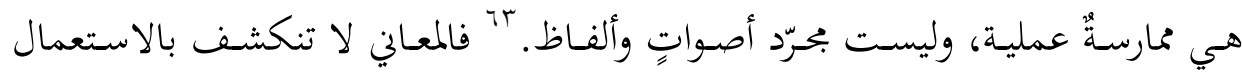

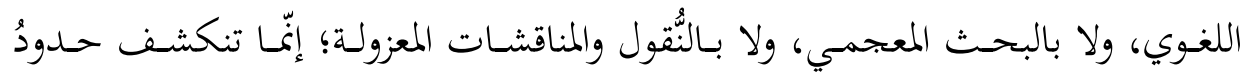

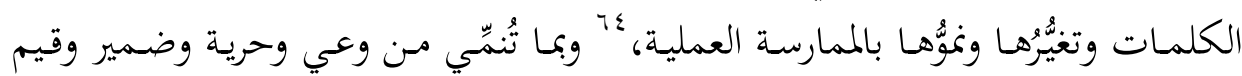

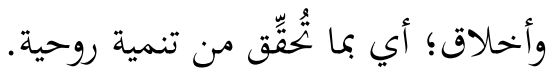

هذه الفصول الثلاثة الأولى هي أخطر فصول هذا الكتاب، ويتناول ناصف بعدها

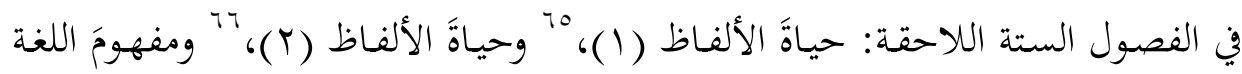

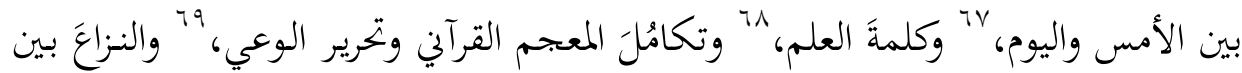

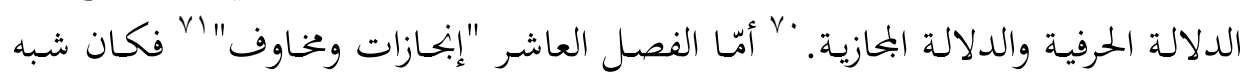

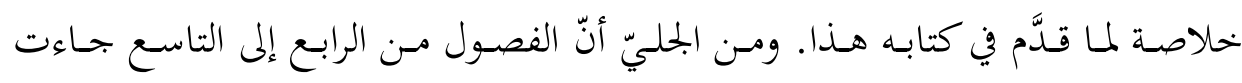

$$
\begin{aligned}
& \text { •" المرجع السابق، صץ • 1. }
\end{aligned}
$$

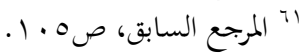

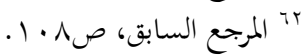

$$
\begin{aligned}
& \text { ז' المرجع السابق، صـ • • 1. }
\end{aligned}
$$

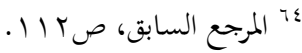

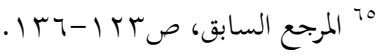

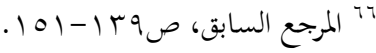

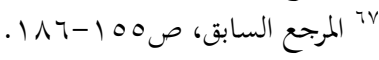

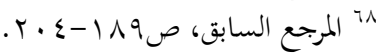

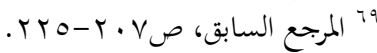

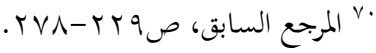

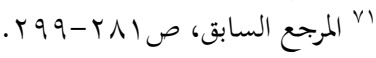


لترسيخ ما عرضَه ناصف من أفكار في الفصول الثلاثة الأولى، أو لتجسيد بعضها بأمثلة

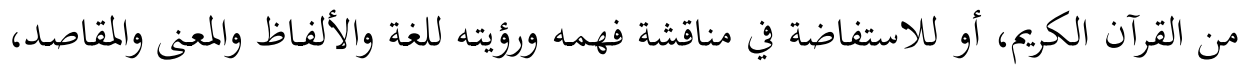

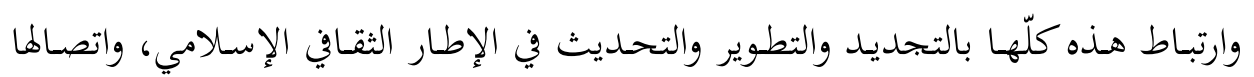

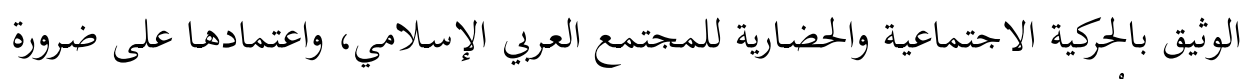

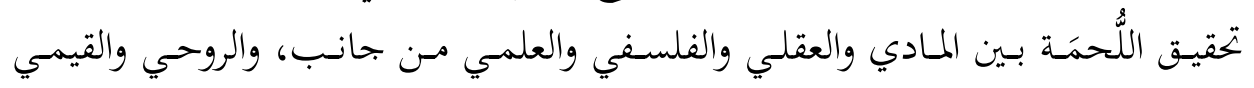
والأخلاقي والوجداني والإنساني من جانب آبن آخر.

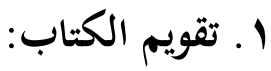

يقـدِّم مصطفى ناصف في كتابـه هـا أُطروحـةً متماسكة مـن جانـب، بمـا تتسلسـُ

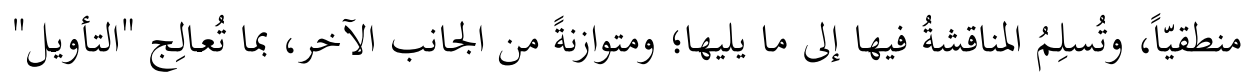

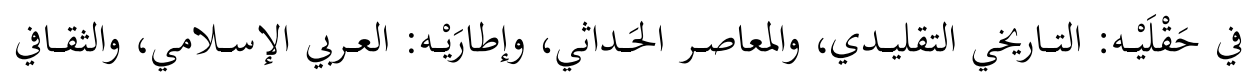

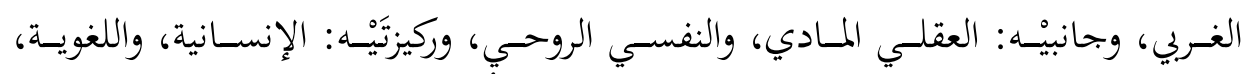

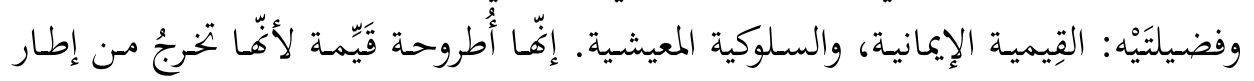

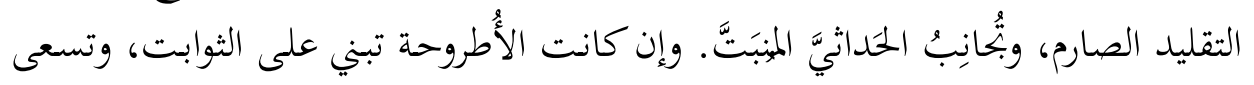

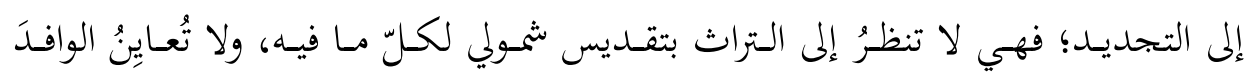

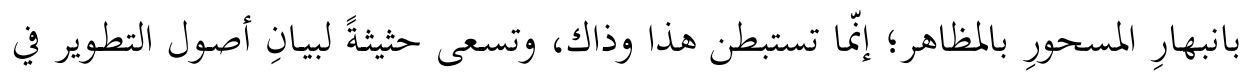

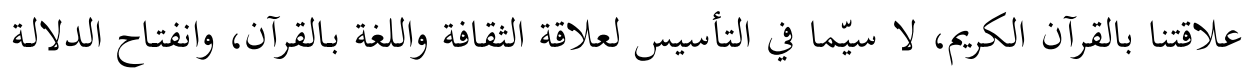

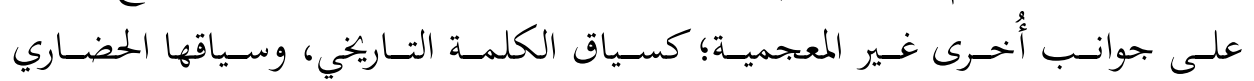

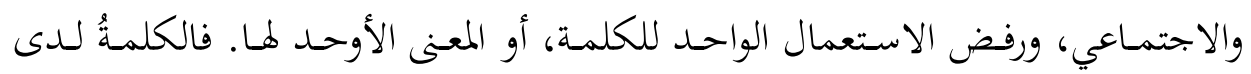

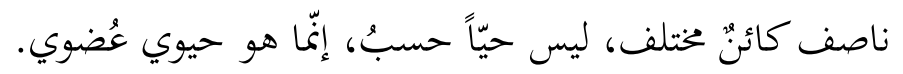

مـن هـا الجحانـب يختلـف هـذا الكتـاب عـن كثير مـن الكتـب التي عالجـت مسـألة

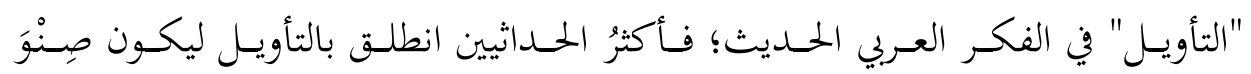

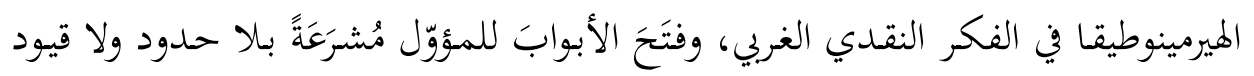

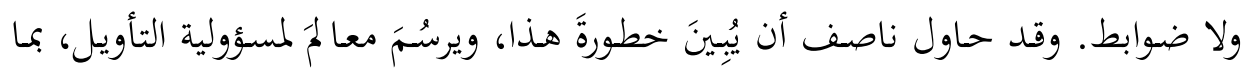

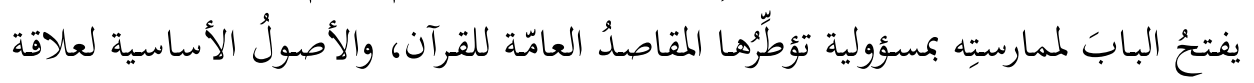

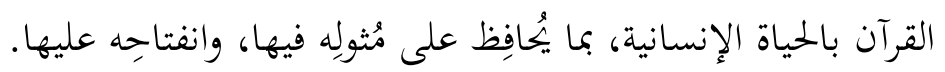




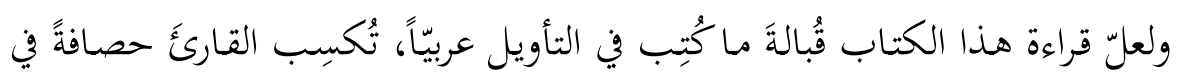

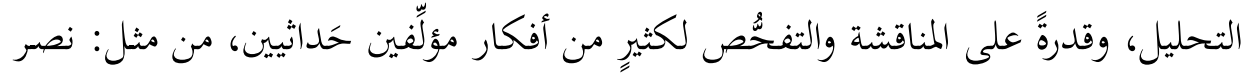

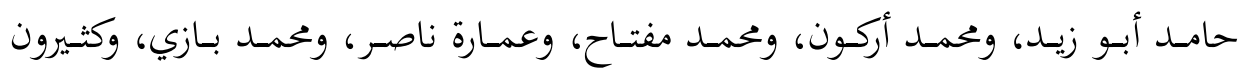
غيرهم.

\section{ب. ب. نقاط الضعف في الكتاب:}

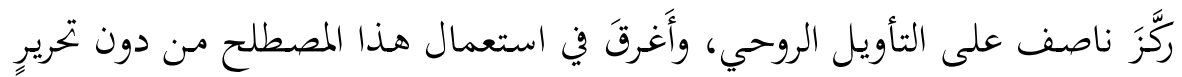

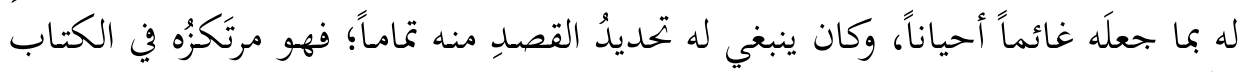

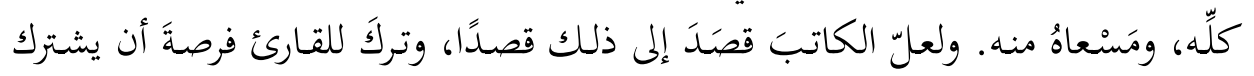

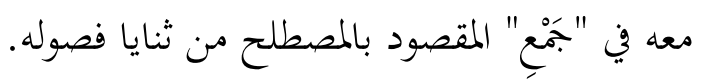

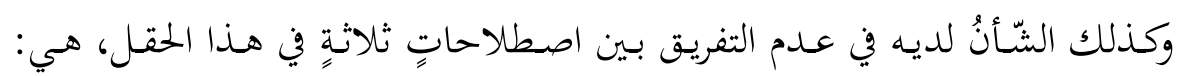

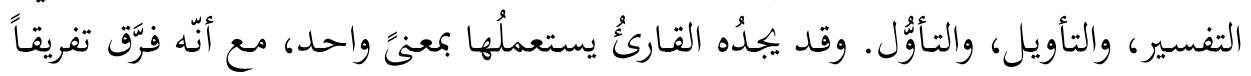

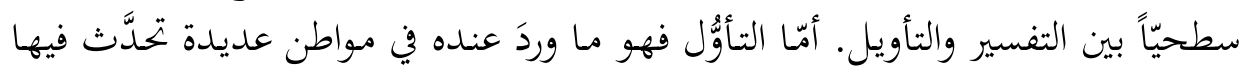

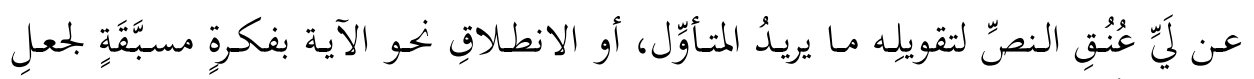
الآية تقولهُا.

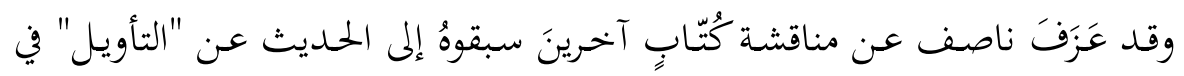

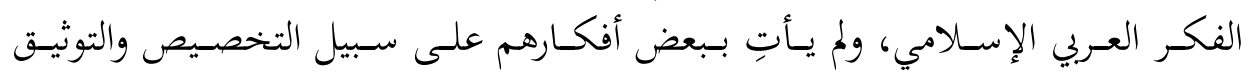

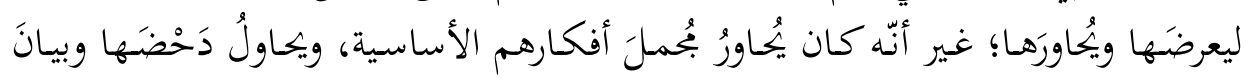
خطوريما.

وقد يلمحُ القارئُ قلََّّ اعتماد المؤلّف على توثيق أفكاره وعباراته؛ ولهذا فقد تكون

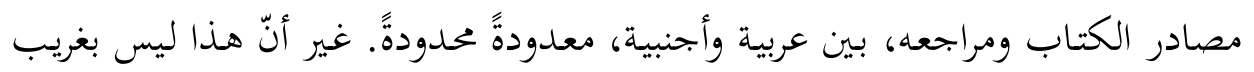

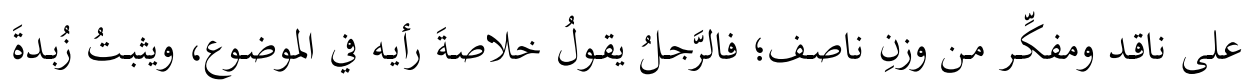

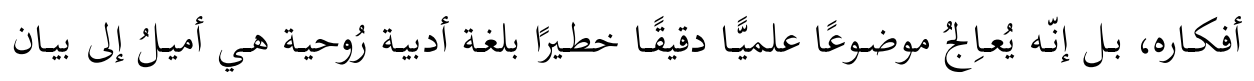
المتصوّف أحايين كثيرة.

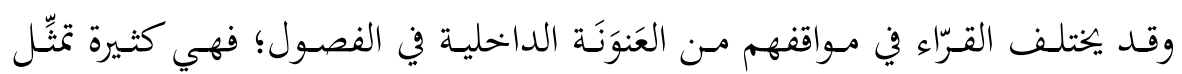

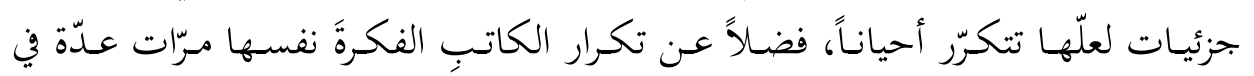




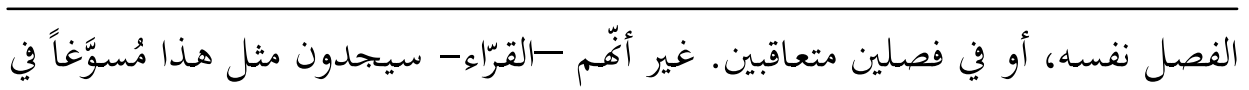

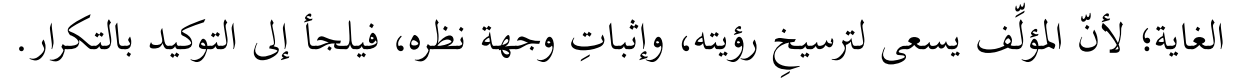
r. مراجع إضافية قد يستعين بها القارئ: قد يستعين القارئ بالمراجع الآتية لاستكمال موضوع الكتاب، أو لمقارنة مادته بما

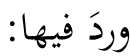

- ناصف، مصطفى. نظرية التأويل، جدّة: النادي الأدبي والثقافي، ... ب بم. - ريكور، بول. مـن النصّ إلى الفعـل: أبحـاث التأويلل، ترجمـة: محمد برادة،

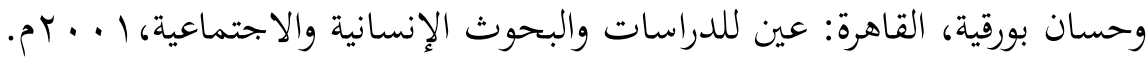

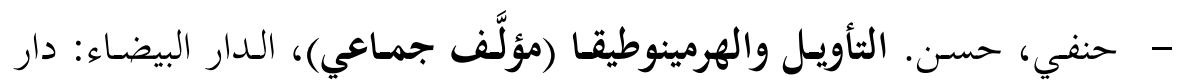

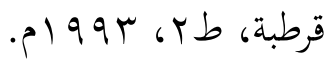
- - مفتـاح، محمدـ. التلقّي والتأويلل: مقاربـة نسقية، الدار البيضـاء: المركز الثقافي

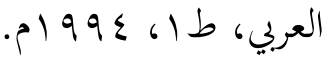
- مفتاح، محمد. المفاهيم معالم: نحو تأويل واقعي، بيروت- الدار البيضاء:

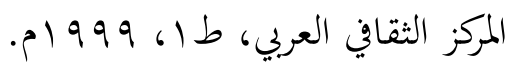

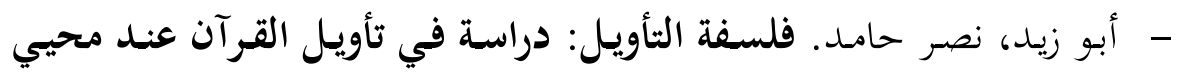

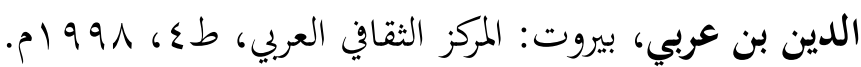
- أبو زيد، نصر حامد. الخطاب والتأويل، بيروت- الدار البيضاء: المركز الثقافي

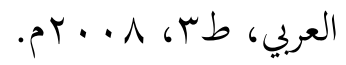

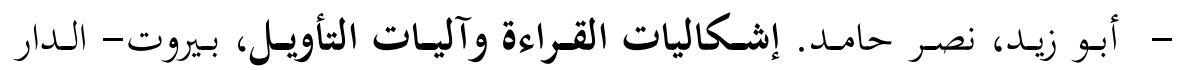

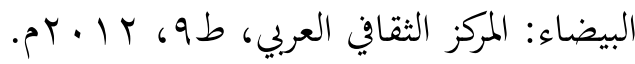

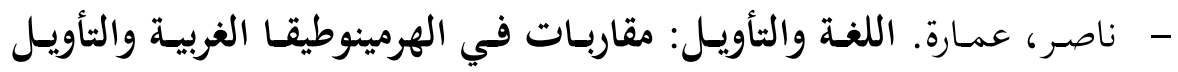

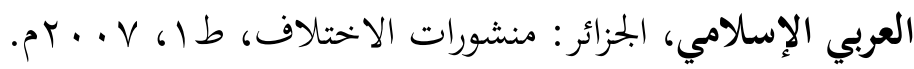

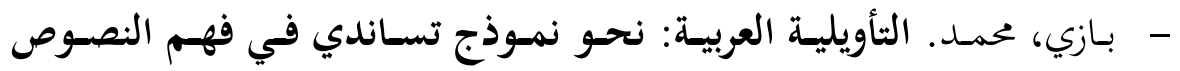

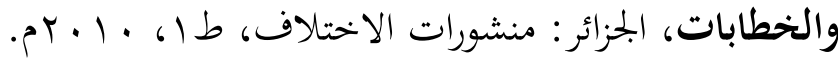

